\title{
Adult Asthma Consensus Guidelines Update 2003
}

\author{
Catherine Lemière $M D^{1}$, Tony Bai $M D^{2}$, Meyer Balter $M D^{3}$, Charles Bayliff PharmD $D^{4}$, Allan Becker $M D^{5}$, \\ Louis-Philippe Boulet $M D^{6}$, Dennis Bowie $M D^{7}$, André Cartier $M D^{1}$, Andrew Cave $M D^{8}$, \\ Kenneth Chapman $M D^{3}$, Robert Cowie $M D^{9}$, Stephen Coyle $M D^{5}$, Donald Cockcroft $M D^{10}$, \\ Francine $M$ Ducharme $M D^{11}$, Pierre Ernst $M D^{11}$, Shelagh Finlayson $C A E^{12}$, J Mark FitzGerald $M D^{2}$, \\ Frederick E Hargreave $\mathrm{MD}^{13}$, Donna Hogg MS RN CAE ${ }^{7}$, Alan Kaplan MD ${ }^{14}$, Harold Kim MD ${ }^{15}$, \\ Cheryle Kelm BPT MSC ${ }^{9}$, Paul O'Byrne MD ${ }^{13}$, Malcolm Sears MD ${ }^{13}$, Andrea White Markham RRT CAE ${ }^{16}$, \\ on behalf of the Canadian Adult Consensus Group of the Canadian Thoracic Society \\ ${ }^{1}$ Université de Montréal, Montreal, Quebec; ${ }^{2}$ University of British Columbia, Vancouver, British Columbia; \\ ${ }^{3}$ University of Toronto, Toronto, Ontario; ${ }^{4}$ London Health Sciences Centre, London, Ontario; \\ ${ }^{5}$ University of Manitoba, Winnipeg, Manitoba; ${ }^{6}$ Université Laval, Sainte-Foy, Quebec; ${ }^{7}$ Dalhousie University, \\ Halifax, Nova Scotia; ${ }^{8}$ University of Alberta, Edmonton, Alberta; ${ }^{9}$ University of Calgary, Calgary, Alberta; \\ ${ }^{10}$ University of Saskatchewan, Saskatoon, Saskatchewan; ${ }^{11}$ McGill University, Montreal, Quebec; \\ ${ }^{12}$ Toronto, Ontario; ${ }^{13}$ McMaster University, Hamilton, Ontario; ${ }^{14}$ Richmond Hill, Ontario; \\ ${ }^{15}$ Kitchener-Waterloo, Ontario; ${ }^{16}$ William Osler Health Centre, Brampton, Ontario
}

C Lemière, T Bai, M Balter, et al, on behalf of the Canadian Adult Consensus Group of the Canadian Thoracic Society. Adult Asthma Consensus Guidelines Update 2003. Can Respir J 2004;11(Suppl A):9A-18A.

BACKGROUND: Several sets of Canadian guidelines for the diagnosis and management of asthma have been published over the past 15 years. Since the last revision of the 1999 Canadian Asthma Consensus Report, important new studies have highlighted the need to incorporate new information into the asthma guidelines.

OBJECTIVES: To review the literature on adult asthma management published between January 2000 and June 2003; to evaluate the influence of the new evidence on the recommendations made in the 1999 Canadian Asthma Consensus Guidelines and its 2001 update; and to report new recommendations on adult asthma management.

METHODS: Three specific topics for which new evidence affected the previous recommendations were selected for review: initial treatment of asthma, add-on therapies in the treatment of asthma and asthma education. The resultant reviews were discussed in June 2003 at a meeting under the auspices of the Canadian Thoracic Society, and recommendations for adult asthma management were reviewed.

RESULTS: The present report emphasises the importance of the early introduction of inhaled corticosteroids in symptomatic patients with mild asthma; stresses the benefit of adding additional therapy, preferably long-acting beta 2 -agonists, to patients incompletely controlled on low doses of inhaled corticosteroids; and documents the essential role of asthma education.

CONCLUSION: The present report generally supports many of the previous recommendations published in the 1999 Canadian Asthma Consensus Report and provides higher levels of evidence for a number of those recommendations.

Key Words: Asthma; Asthma education; Guidelines; Inhaled corticosteroids; Leukotriene receptor antagonists; Long-acting beta $2_{2}$ agonists

\section{Background}

\section{INTRODUCTION}

The first Canadian guidelines for the diagnosis and management of asthma in Canada were established by a panel of Canadian and international specialists under the leadership of FE Hargreave in 1989 (1). Subsequent meetings in 1995 (2) and 1998 (3), under the auspices of the Canadian Thoracic Society (CTS), led to the revision of the previously published Canadian guidelines. The Canadian Asthma Consensus Report 1999 (3) was widely disseminated and remains a primary reference. A revision of these guidelines followed in 2001 (4) and focused on new information that affected the earlier recommendations. Since this last revision, important new studies highlight the need to incorporate new information into the asthma guidelines and to address specific issues in childhood asthma not previously addressed comprehensively.

A complete review of the guidelines is complicated and unnecessary in many sections in which new evidence does not significantly affect previous recommendations. Therefore, the Asthma Committee of the CTS agreed to focus on specific issues related to adult asthma, while the Pediatric Consensus Committee of the Canadian Network for Asthma Care (CNAC) focused on specific issues in childhood asthma.

Stakeholders in adult and pediatric asthma met for two days in Montreal, Quebec on June 27 and 28, 2003. The 'adult' group met under the auspices of the CTS, and the 'pediatric'

Correspondence: Dr Catherine Lemière, Service de pneumologie, Hôpital du Sacré-Coeur, 5400 Boulevard Gouin Ouest, Montreal, Quebec H4J 1C5. Telephone 514-338-2796, fax 514-338-3123, e-mail C-Lemiere@crhsc.umontreal.ca

Reprints: Ms Valoree McKay, Canadian Thoracic Society, 3 Raymond Street, Suite 300, Ottawa, Ontario K1R 1A3. Telephone 613-569-6411, fax 613-569-8860 
TABLE 1

Levels of evidence

\begin{tabular}{|c|c|}
\hline Level I & $\begin{array}{l}\text { Evidence is based on randomized, controlled trials (or } \\
\text { meta-analysis of such trials) of adequate size to ensure a } \\
\text { low risk of incorporating false-positive or false-negative results. }\end{array}$ \\
\hline Level II & $\begin{array}{l}\text { Evidence is based on randomized, controlled trials that are too } \\
\text { small to provide Level I evidence. They may show either positive } \\
\text { trends that are not statistically significant or no trends and are } \\
\text { associated with a high risk of false-negative results. }\end{array}$ \\
\hline
\end{tabular}

Level III Evidence is based on nonrandomized, controlled or cohort studies, case series, case-control studies or cross-sectional studies.

Level IV Evidence is based on the opinion of respected authorities or expert committees as indicated in published consensus conferences or guidelines.

Level $\mathrm{V}$ Evidence is based on the opinions of those who have written and reviewed the guidelines, based on their experience, their knowledge of the relevant literature and discussion with their peers.

Data from reference 5

\section{TABLE 2}

\section{Overall management of asthma}

\begin{tabular}{|c|c|}
\hline Suspect asthma & Make differential diagnosis \\
\hline $\begin{array}{l}\text { Confirm the diagnosis and assess } \\
\text { initial severity }\end{array}$ & $\begin{array}{l}\text { Evaluate symptoms and measure } \\
\text { pulmonary function tests } \\
\text { (spirometry or peak expiratory flows) }\end{array}$ \\
\hline $\begin{array}{l}\text { Determine possible triggers and } \\
\text { inducers of asthma }\end{array}$ & $\begin{array}{l}\text { Perform a questionnaire, allergy } \\
\text { tests or other tests (to assess } \\
\text { environment, workplace, etc) }\end{array}$ \\
\hline Initiate treatment & $\begin{array}{l}\text { Prescribe the medication required } \\
\text { to achieve asthma control; treat } \\
\text { associated conditions (eg, rhinitis) }\end{array}$ \\
\hline Initiate education & $\begin{array}{l}\text { Provide basic elements and, if } \\
\text { possible, refer patients to an } \\
\text { asthma educator }\end{array}$ \\
\hline $\begin{array}{l}\text { Determine the best results } \\
\text { achievable }\end{array}$ & $\begin{array}{l}\text { Check asthma control criteria, } \\
\text { including pulmonary function }\end{array}$ \\
\hline $\begin{array}{l}\text { Determine the minimum medication } \\
\text { needed to keep the asthma } \\
\text { controlled }\end{array}$ & $\begin{array}{l}\text { Progressively reduce the } \\
\text { medication while checking asthma } \\
\text { control }\end{array}$ \\
\hline $\begin{array}{l}\text { Devise an action plan for the } \\
\text { management of exacerbations }\end{array}$ & $\begin{array}{l}\text { Provide a written document or ask } \\
\text { an asthma educator to do so }\end{array}$ \\
\hline Ensure regular follow-up & $\begin{array}{l}\text { Regularly check control criteria and } \\
\text { pulmonary function }\end{array}$ \\
\hline
\end{tabular}

Data from reference 4

group met under the auspices of CNAC. The two groups met separately on the first day to discuss the issues specific to each group and met together on the second day to discuss dissemination and implementation of the asthma guidelines.

The present document deals only with the topics related to the management of adult asthma; the recommendations on childhood asthma will be published separately. The Asthma Committee of the CTS asked a panel of Canadian asthma specialists to perform literature reviews of specific issues related to the management of adult asthma. The experts were chosen for their work and contributions in the field of asthma. The panel systematically reviewed English language studies published between January 1, 2000 and June 2003. During the first day of the June meeting, the whole group reformulated some recommendations based on the literature review to incorporate concerns and suggestions until a consensus on the specific question was achieved.
TABLE 3

\section{Asthma control criteria}

Daytime symptoms less than four days per week

Night-time symptoms less than one night per week

Normal physical activity

Mild, infrequent exacerbations

No absenteeism due to asthma

Fewer than four doses per week of a fast-acting beta ${ }_{2}$-agonist needed*

Forced expiratory volume in $1 \mathrm{~s}$ or peak expiratory flow at $90 \%$ of their personal best or greater

Diurnal variability in peak expiratory flow of less than $10 \%$ to $15 \%$

Data from reference 4. *Apart from one dose/day before exercise

The group based its recommendations on a critical review of the literature and assigned a level to each based on the strength of the supporting evidence (Table 1) (5). The document was subsequently circulated to the whole group and revised according to the group's comments and consensus.

\section{Definition of asthma}

The definition of asthma is descriptive and has not changed since the last guidelines (3). Asthma is characterized by paroxysmal or persistent symptoms such as dyspnea, chest tightness, wheezing, sputum production and cough, associated with variable airflow limitation and airway hyper-responsiveness to endogenous or exogenous stimuli. Inflammation and its resultant effects on airway structure are considered to be the main mechanisms leading to the development and maintenance of asthma.

This 1999 definition remains valid. Airway inflammation is the primary hallmark of asthma, and better understanding of the underlying pathophysiological mechanisms is important in improving treatment. Indeed, the development of molecules directly targeting specific components of the immune system, such as immunoglobulin E, are the result of this improved understanding and may herald the future for asthma treatment (6).

\section{General management of asthma}

Optimal management of asthma requires adequate evaluation of the patient and thorough evaluation of environmental factors for that patient (Table 2) (3). When evaluating a new patient, a clinician can assess asthma control by reviewing previously published, but still valid, criteria (Table 3) (3). It is more difficult to assess asthma severity at this early stage, and assessment may be possible only after the asthma is controlled. However, as recommended in the section on mild asthma, treatment with inhaled corticosteroids (ICSs) should be considered early, even in subjects who report asthma symptoms fewer than three times per week. The dose equivalencies used for ICSs in this document (Table 4) were published in the 1999 Canadian Asthma Guidelines (3).

The present consensus update generally supports many of the previous recommendations and provides higher levels of evidence for some of those recommendations.

A central focus of the previous consensus report (3) was the concept of asthma management as a continuum. That management continuum has been modified slightly to reflect the new recommendations presented here (Figure 1). 
TABLE 4

Proposed dose equivalencies for inhaled corticosteroids

\begin{tabular}{lccc}
\hline Product & Low & $\begin{array}{c}\text { Daily dose }(\mu \mathrm{g} / \text { day }) \\
\text { Medium }\end{array}$ & High \\
\hline BDP pMDI and spacer & $\leq 500$ & $501-1000$ & $>1000$ \\
BUD Turbuhaler* $^{*}$ & $\leq 400$ & $401-800$ & $>800$ \\
FP pMDI and spacer & $\leq 250$ & $251-500$ & $>500$ \\
FP Diskus $^{\dagger}$ & $\leq 250$ & $251-500$ & $>500$ \\
BDP pMDI (HFA) $^{\ddagger}$ & $\leq 250$ & $251-500$ & $>500$ \\
BUD wet nebulization $^{\S}$ & $\leq 1000$ & $1001-2000$ & $>2000$
\end{tabular}

*Budesonide (BUD) Turbuhaler (AstraZeneca Inc, Canada); 'Fluticasone propionate (FP) Diskus (GlaxoSmithKline Canada Inc, Canada): IIn solution with alcohol (QVAR, 3M Pharmaceuticals, Canada) - other hydrofluoralkane (HFA) (propellant) inhalers may provide dose equivalencies similar to BDP delivered with a traditional pressurized metered-dose inhaler (pMDI); \$Budesonide solution for wet nebulization (AstraZeneca Inc, Canada). BDP Beclomethasone dipropionate

\section{Medications}

New therapies targeting the immune system are under investigation for the treatment of asthma. Omalizumab, an antiimmunoglobulin E antibody, has received Food and Drug Administration approval for use in the United States, but is not yet available in Canada (6). The present document focuses on currently available medications in Canada, including ICSs, short- and long-acting beta 2 -agonists (LABAs), leukotriene receptor antagonists (LTRAs) and theophylline. Usually, poor asthma control is not a result of ineffectiveness of the medication, but of suboptimal use of that medication, inattention to aggravating factors, poor inhaler technique, poor environmental control or a lack of continuity of care.

\section{Dissemination and implementation of the guidelines}

The dissemination and implementation of these guidelines are critical for improvement of the management of asthma. An implementation committee comprising representatives of various organizations involved in the field of asthma, as well as representatives from the pharmaceutical industry, will be charged to disseminate and implement the content of these guidelines concomitantly with the pediatric asthma guidelines.

\section{Conclusions}

The recommendations in this document should be considered to be a guide for asthma management based on currently available evidence. However, each patient with asthma needs to be evaluated individually and objectively with respect to specific outcomes, including symptoms, lung function and occurrence of adverse events. Asthma control and maintenance therapy should be assessed at each visit. Any alteration in medication therapy should be considered a trial and effectiveness re-evaluated after a reasonable period of time.

Additional tools that are currently under investigation, such as induced sputum (7) or exhaled nitric oxide (8), may help to characterize better the level of airway inflammation and improve the management of asthma.

\section{THE ROLE OF ICSs IN THE INITIAL MANAGEMENT OF ASTHMA}

\section{Background}

The inflammatory nature of asthma and the importance of anti-inflammatory therapy is well established in all asthma

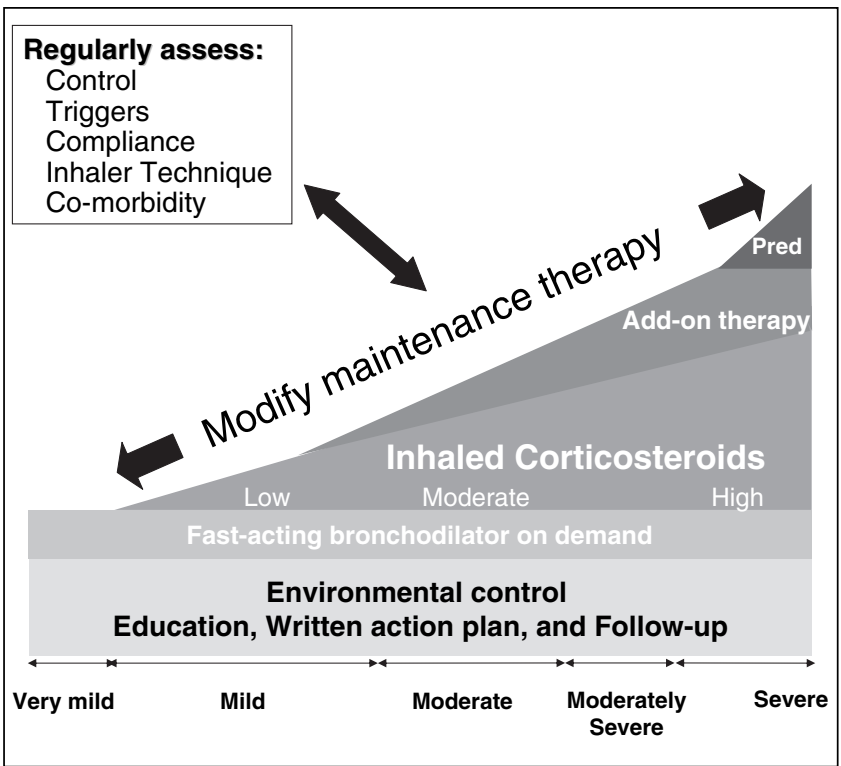

Figure 1) Continuum of asthma management. Very mild asthma is treated with short-acting beta $a_{2}$-agonists, taken as needed. Inhaled corticosteroids (ICSs) may be introduced as the initial maintenance treatment for asthma, even in subjects who report asthma symptoms less than three times per week. For patients who cannot or will not use ICSs, leukotriene receptor antagonists are an alternative, although they are less effective than low doses of ICSs. If asthma is not adequately controlled by low doses of ICSs, additional therapy should be considered. Addition of long-acting beta -agonists should be considered as the first option. As an alternative, addition of leukotriene receptor antagonists or increasing ICSs to a moderate dose of may be considered. Theophylline may be considered as a third therapeutic option. Severe asthma may require additional treatment with prednisone (Pred). Asthma control should be assessed at each visit, and maintenance therapy should be altered if necessary. Any alteration in medication therapy should be considered a trial, and effectiveness should be re-evaluated after a reasonable period of time. After achieving full control, the medication should be reduced to the minimum necessary to maintain control

guidelines $(3,9,10)$. Based on a series of studies in patients who remain poorly controlled despite ICSs, the addition of a LABA has been found to be better than doubling the dose of ICS $(11,12)$. Three major questions remain:

1. What is the optimal time to start ICSs in mild asthma?

2. Which patients may benefit from the initiation of combination therapy instead of ICSs alone?

3. What are the relative merits of the use of ICSs versus LTRAs in mild asthma?

We reviewed the evidence supporting the role of ICSs in mild asthma and critically evaluated the evidence relating to the three questions. This brief systematic review was limited to studies published since 2000 . We also requested information about any unpublished papers or data on file within the last three years from all companies who market the relevant drugs.

\section{ICSs in mild asthma}

There are many studies on the role of ICSs in mild to moderate asthma. Before the period of our review, we identified two 
systematic reviews $(13,14)$. One (13) identified 52 studies including 3459 subjects. Beclomethasone showed significant improvements in forced expiratory volume in $1 \mathrm{~s}\left(\mathrm{FEV}_{1}\right)$ (weighted mean difference $340 \mathrm{~mL}, 95 \%$ CI 190 to $500 \mathrm{~mL}$ ), $\mathrm{FEV}_{1}$ (\% predicted) (weighted mean difference 6\%, 95\% CI $0.4 \%$ to $11.5 \%$ ) and morning peak expiratory flow (PEF) (weighted mean difference $50 \mathrm{~L} / \mathrm{min}, 95 \% \mathrm{CI} 8$ to $92 \mathrm{~L} / \mathrm{min}$ ) in all studies compared with placebo. In addition to a reduction in the use of short-acting beta ${ }_{2}$-agonists, subjects who used ICSs were less likely to have been withdrawn because of an asthma exacerbation (risk ratio [RR] 0.54, 95\% CI 0.15 to $0.43)$ than those on placebo. Additional systematic reviews $(13-16)$ have confirmed the primary role of various ICSs in chronic asthma and have generally shown minimal benefit to increasing ICSs above low doses for patients with mild asthma. The overall interpretation from these studies is that ICSs provide the optimal intervention for patients with mild persistent asthma.

\section{Early use of ICSs in mild asthma}

Despite the weight of evidence, the rationale for the early use of ICSs in mild, persistent asthma has been unclear and has not always convinced physicians to begin treatment with ICSs. In a large, prospective study designed to address this issue - the START study (17) - 7241 patients were randomly assigned to inhaled budesonide (adult patients, $400 \mu$ daily; children, $200 \mu \mathrm{g}$ daily) or placebo. Patients had a baseline $\mathrm{FEV}_{1}$ of $86.6 \%$, with a postbronchodilator value of $96.2 \%$. More than $91 \%$ of the patients had symptoms on one or more days in the two weeks before assignment and had not previously been treated with ICSs. The early use of ICSs was associated with better control of symptoms but, most importantly, a significant $44 \%$ reduction in severe exacerbations of asthma (RR 0.56, $95 \%$ CI 0.45 to $0.71, \mathrm{P}<0.0001)$. The patients also had an improved $\mathrm{FEV}_{1}$ compared with baseline (1.48\% after one year, $\mathrm{P}<0.0001 ; 0.88 \%$ after three years, $\mathrm{P}<0.0001)$. Patients assigned to the treatment group were less likely to need additional anti-inflammatory therapy.

\section{ICSs versus combination therapy in mild asthma}

Combining a LABA and ICSs has been well established in the management of moderate to severe asthma (18). Less clear-cut is the role of combination therapy in mild to moderate asthma. Few studies have addressed this issue directly. In one study (19), 698 patients (group A) were randomly assigned to receive a low dose ICS (100 $\mu$ g budesonide twice daily) and a LABA ( $6 \mu \mathrm{g}$ formoterol twice daily), an ICS alone $(100 \mu \mathrm{g}$ budesonide twice daily) or placebo. The addition of $6 \mu \mathrm{g}$ of formoterol to the ICS resulted in improved lung function, but no additional benefit was found when compared with budesonide alone (100 $\mu$ g twice daily). Compared with placebo, even in this population of patients with mild asthma, the addition of an ICS resulted in a $68 \%$ reduction in severe exacerbations. Of 1272 patients treated previously with ICSs - group B of the same study (19) - who had slightly worse lung function (mean $\mathrm{FEV}_{1}$ per cent predicted value $86 \%$ compared with $90 \%$ ), the addition of formoterol gave additional benefit compared with placebo and, more importantly, compared with doubling of the dose of the ICS.
A small, open, nonrandomized, before and after study of salmeterol and fluticasone evaluated 127 patients for four weeks with 'mild to moderate' asthma. Subjects had a mean $\mathrm{FEV}_{1}$ of $2.68 \pm 0.7 \mathrm{~L}$ (82.2\% predicted) at baseline (20). There was a significant improvement in asthma control in these patients, but the design of the study - small, open and nonrandomized - precludes using the study to make treatment recommendations.

\section{ICSs versus LTRAs in mild asthma}

As outlined above, ICSs have usually been the initial treatment recommended for mild asthma. An alternative therapy is the use of an LTRA. A recent systematic review compared the effect of ICSs (400 $\mu$ g of beclomethasone or equivalent) with LTRAs in mild asthma (21). The author identified 13 trials (all of adults except for one study). Patients treated with LTRAs were $60 \%$ more likely to suffer an asthma exacerbation that required a course of oral prednisone than patients using ICSs (RR 1.6, 95\% CI 1.2 to 2.2). In addition, patients using ICSs had better symptom control and lung function. Patients allocated to treatment with an LTRA were much more likely to be withdrawn from the studies because of poor asthma control (RR 2.5, 95\% CI 1.8 to 3.5 ).

\section{Other publications}

Our literature search identified 26 other papers (22-47) published in the past three years. Most of these papers were excluded because they had been integrated, in many instances, into recent systematic reviews or they included studies addressing the relative benefits of combination therapy with LABAs and ICSs rather than our primary question, which addressed the early use of ICSs. We also excluded studies if patients were already taking ICSs or if the studies did not include a placebo arm.

\section{Recommendations}

These recommendations are based on the following definition of mild asthma: intermittent symptoms of asthma, requiring a short-or fast-acting beta ${ }_{2}$-agonist at least twice weekly to control symptoms, with an $\mathrm{FEV}_{1}$ greater than $85 \%$ predicted.

1. ICSs should be introduced early as the initial maintenance treatment for symptomatic asthma (Level I evidence).

2. There is insufficient evidence of additional benefit for the initial use of combination therapy in those with mild, symptomatic asthma who have not previously been treated with ICSs (Level I evidence).

3. For patients who cannot or will not use ICSs, LTRAs are an alternative (Level I evidence). However, LTRAs as monotherapy are less effective than low doses of ICSs (Level I evidence).

4. Doses of ICSs recommended in mild asthma are safe (Level III evidence).

\section{Suggestions for future research}

1. What is the minimal effective dose of ICSs in the treatment of asthma?

2. Can the regular use of ICSs modify the natural history of asthma?

3. Can the monitoring of airway inflammation improve the management of asthma? 
4. In mild asthma, a significant proportion of patients experience severe exacerbations. The optimal strategy for the prevention of such exacerbations progressing from an early increase in symptoms to a severe asthma exacerbation needs to be defined.

\section{Implementation strategies}

The key message for family physicians is that we have excellent evidence supporting the early introduction of ICSs in mild asthma. There is no evidence currently supporting the use of combination therapy as first-line treatment for mild asthma as defined previously. Physician and patient education should focus on the recent clinical research that has confirmed the role for the early introduction of ICSs in asthma. Patient education needs to focus on the benefits to the patient and provide reassurance about the safety of ICSs in the doses required to control mild asthma.

\section{ADD-ON THERAPIES IN THE TREATMENT OF ASTHMA}

\section{Introduction}

While ICSs remain the cornerstone of controller therapy for asthma, at least three different classes of medications have been identified as useful add-on therapies in patients not adequately controlled with ICSs: inhaled LABAs (11), oral LTRAs (48) and oral theophylline (49). Each has been shown to improve asthma control or allow for a reduction in the dose of ICS.

We sought to evaluate and compare each medication's efficacy when added to treatment with ICSs, as well as its corticosteroid-sparing effect.

A systematic review of trials published in English since the last asthma guideline update, between January 1, 2000 and June 2003, was performed using PubMed. The key words used were "advair", "antileukotrienes", "formoterol”, "long-acting beta agonists", "montelukast”, "salmeterol”, "seretide”, "serevent”, "oxeze”, "oxis", "symbicort", "theophylline" and "zafirlukast". GlaxoSmithKline, AstraZeneca and Merck Frosst were contacted to obtain the latest unpublished studies involving their products. We also had access to the Cochrane Library.

Predictably, most studies were industry sponsored. Interpretation of these studies required consideration of possible biases in study design, interpretation or publication. Furthermore, an old and inexpensive drug such as theophylline may have been disadvantaged, because it was unlikely to receive any corporate sponsorship for expensive, large studies of add-on therapy; indeed, little on this drug has been published.

\section{LABAs}

For several years, LABAs have been established as an effective and safe medication, when used with ICSs, for providing good control of asthma in patients not optimally controlled on a moderate-dose ICS (12). Their use as monotherapy has been assessed $(50,51)$. Recent studies investigated the efficacy of the combination of a LABA with a low dose of ICS in comparison with a higher dose of ICS alone; others evaluated the corticosteroid-sparing effect of the addition of a LABA.

\subsection{LABAs as monotherapy for asthma treatment}

Salmeterol monotherapy does not provide satisfactory control of asthma. A randomized, double-blind, placebo controlled, parallel-group study compared triamcinolone $(400 \mu \mathrm{g}$ twice daily) with salmeterol (42 $\mu$ g twice daily) (50). Despite reasonable control of symptoms and lung function, treatment failure and asthma exacerbations occurred more often in the salmeterol-treated group. A study evaluating the corticosteroidsparing effect of LABAs noted a large increase in asthma exacerbations (46.3\% of patients) after complete elimination of triamcinolone compared with subjects taking both trimaciolone $(400 \mu$ g twice daily) and salmeterol (13.7\% of patients) (51). This has recently been confirmed with the interim analysis of the recently discontinued SMART study, which demonstrated that salmeterol was associated with a significantly higher prevalence of adverse events, including death, than a placebo in the approximately $50 \%$ of 26,000 subjects who were not on ICSs (52).

\subsection{LABAs versus placebo as add-on therapy to ICSs}

Several pivotal studies in adults have clearly demonstrated the superiority of adding a LABA to moderate doses of an ICS compared with doubling the dose of an ICS to improve asthma control $(11,12,18,53)$. More recently, Zetterstrom et al (54) compared combination inhaler budesonide $(200 \mu \mathrm{g})$ and formoterol $(6 \mu \mathrm{g})$ with the two inhalers separately and with budesonide (200 $\mu$ g, two puffs twice daily) alone in 362 subjects. Both combinations were superior to the ICS alone in symptoms, lung function and asthma control. D'Urzo et al (55) compared salmeterol with placebo as add-on therapy in general practice settings in 712 subjects who had asthma and were taking ICSs. They found improvements in symptoms and expiratory flow rates, but no difference in exacerbation rates.

\subsection{LABAs as add-on therapy to low-dose ICSs versus doubled doses of ICSs}

Heyneman et al (56) reviewed four clinical trials that compared salmeterol and low-dose fluticasone in combination with fluticasone alone. Only one of these studies was placebo controlled. This review included the study by Matz et al (39), which itself is a combination of two studies. Three of these four studies found that the combination of salmeterol $50 \mu \mathrm{g}$ and fluticasone $100 \mu \mathrm{g}$ was superior, in most aspects, to fluticasone $(250 \mu \mathrm{g}$ twice daily) alone. The exacerbation rate was lower with the combination of salmeterol and fluticasone in only one study (39). Only one study compared low- to moderate-dose fluticasone (100 to $250 \mu \mathrm{g}$ twice daily) plus salmeterol with moderateto high-dose fluticasone (250 to $500 \mu$ twice daily) (42). In this study, the combination therapy provided marginal superiority to monotherapy with an ICS (42). The authors concluded that the combination of salmeterol and low-dose fluticasone is superior to monotherapy with moderate-dose fluticasone. In the post hoc combination of two trials, Matz et al (39) used these large data sets (925 subjects) to demonstrate a decreased exacerbation rate, as had been shown in the FACET study (11), with fluticasone $100 \mu \mathrm{g}$ and salmeterol $50 \mu \mathrm{g}$ twice daily compared with fluticasone $(250 \mu$ g twice daily). Indeed, 41 patients (8.8\%) experienced 47 exacerbations with the addition of salmeterol compared with the 63 patients (13.8\%) who experienced 75 exacerbations in the group receiving an increased dose of fluticasone $(\mathrm{P}=0.017)$. 


\subsection{LABAs versus placebo as add-on therapy to tapered doses of ICSs}

A LABA may be used in addition to an ICS to reduce the ICS dose. Several studies assessed the corticosteroid-sparing effect of a LABA. Lemanske et al (51) studied salmeterol (50 $\mu \mathrm{g}$ twice daily) in addition to triamcinolone $(400 \mu \mathrm{g}$ twice daily) in 154 subjects; one-half of this group was assigned to a $50 \%$ reduction in triamcinolone, followed by complete reduction. There was a small $(n=21)$ placebo control group. The primary end point was 'treatment failure', which was three-fold, but not significantly greater, after a $50 \%$ reduction in triamcinolone dose at eight weeks, and which was highly significantly greater (46\% versus $14 \%$ ) after complete elimination of triamcinolone after an additional eight weeks. The authors concluded that addition of the LABA allowed a 50\% reduction in the ICS. Critics of this study argued that in the group in which the dose of ICS was halved, the number of treatment failures might have increased significantly if the duration of study was longer and if the sample size had been increased (57). They also questioned the study's conclusions.

Price et al (43) studied 663 subjects randomly assigned to receive budesonide ( $400 \mu \mathrm{g}$ twice daily) with either placebo or formoterol (12 $\mu$ g twice daily) for four weeks followed by random reassignment of 505 subjects with good asthma control to a reduced dose of budesonide ( $400 \mu$ g once daily) with placebo or formoterol ( $12 \mu \mathrm{g}$ twice daily). Formoterol resulted in more rapid achievement of asthma control in the first four weeks of the study. In the subsequent six-month trial, formoterol plus low-dose budesonide was more effective than low-dose budesonide alone in all aspects, including time to first mild asthma exacerbation. However, the exclusion of the subjects who were not well controlled on treatment combining budesonide and formoterol may have introduced a selection bias.

Busse et al (26) studied 760 subjects. During the first run-in period, patients received fluticasone $250 \mu \mathrm{g}$ twice daily or the equivalent for 10 to 14 days. Controlled patients moved to the second run-in period where they received fluticasone $100 \mu \mathrm{g}$ twice daily. Only patients who became unstable on fluticasone $100 \mu \mathrm{g}$ twice daily were eligible to enter the third run-in period during which they were placed on fluticasone $250 \mu \mathrm{g}$ twice daily. Those regaining asthma control were eligible for randomization. The authors randomly assigned 277 patients to stay with the same treatment, and assigned 281 subjects to receive the combination treatment, including fluticasone $(100 \mu \mathrm{g})$ and salmeterol $(50 \mu \mathrm{g})$ twice daily. The proportion of subjects in each group who remained in the study with no evidence of worsening asthma was the same, as was the total number of exacerbations. PEF rates were higher and salbutamol use was lower in the salmeterol group. The authors concluded that the use of salmeterol allowed for a $60 \%$ decrease in the fluticasone dose. However, only one dose reduction was performed, and the magnitude of the corticosteroid-sparing effect may have been overestimated in this study. Indeed, a dose of $350 \mu \mathrm{g}$ of fluticasone instead of $500 \mu \mathrm{g}$ may have been sufficient to obtain satisfactory control of asthma in the group without a LABA.
Therefore, the use of LABAs seems to allow for a reduction in the dose of ICSs, but additional studies are needed to establish the magnitude of the corticosteroid-sparing effect and its clinical relevance. In any case, an appropriate dose of ICS should be maintained to avoid the occurrence of asthma exacerbations.

\section{LTRAs}

\subsection{LTRAs versus placebo as add-on therapy to ICSs}

A recent meta-analysis (58) that pooled the randomized, controlled trials comparing LTRAs with placebo as add-on therapy to ICSs revealed that montelukast caused a small but significant improvement in PEF, as well as a reduction in beta ${ }_{2}$-agonist use and eosinophil count. However, the use of montelukast did not decrease the risk of exacerbations compared with placebo. Only when used at higher doses than that approved for use did pranlukast (450 mg twice daily) or zafirlukast ( $80 \mathrm{mg}$ twice daily) decrease the risk of exacerbations.

Montelukast was compared with placebo in 100 subjects with poorly controlled asthma who were generally on highdose ICSs, and most were already on one or two add-on therapies (59). In this study, performed to simulate the 'real world' of poorly controlled asthma, the effect of montelukast was no different from that of the placebo. However, strong criticism resulted in pointing out the biases against an LTRA in a group already on extensive therapy $(60,61)$. As has been previously described (62), the two most common reasons for such high medication requirements with suboptimal control are, first, noncompliance with medication, and second, the possibility that some or perhaps even all symptoms could be the result of something other than asthma (61) .

A double-blind, randomized, crossover study (63) compared fluticasone (100 $\mu$ twice daily) plus placebo with fluticasone $(100 \mu \mathrm{g}$ twice daily) plus montelukast (10 mg daily) in 28 subjects and found no significant difference between the two in symptoms, lung function and inflammatory markers. A double-blind, multicentre study (64) compared the addition of montelukast to placebo in patients with asthma that were poorly controlled on ICSs (400 to $1600 \mu \mathrm{g}$ daily). The authors found that compared with the control group, the montelukast-treated group had more asthma-free days, less beta $_{2}$-agonist use and improved PEF values. Therefore, the addition of montelukast to an ICS seems to provide a small improvement in asthma control in subjects incompletely controlled by ICSs.

\subsection{LTRAs as add-on therapy versus doubled doses of ICSs} A recent meta-analysis (58) reported that only two unpublished trials compared zafirlukast as add-on therapy with doubled doses of ICSs. When zafirlukast was used at four times the approved dose, there were no significant differences in the risk of asthma exacerbations, PEF, symptom score and beta $2^{-}$ agonist use between groups, but the power of the study was insufficient to claim equivalency.

The addition of montelukast $(10 \mathrm{mg})$ to budesonide $(800 \mu \mathrm{g}$ daily) appeared as effective as budesonide (1600 $\mu \mathrm{g}$ daily) in 889 subjects who were symptomatic after a 30-day run-in on 
budesonide ( $800 \mu \mathrm{g}$ daily) (65). Improvements in PEF, quality of life and blood eosinophil count were similar between the two groups. The effect on exacerbations was also similar; however, to prove equivalency, several thousand patients would be required. Thus, although the addition of an LTRA to a moderate dose of an ICS appears to be as effective as doubling the doses of an ICS, equivalency has not yet been demonstrated.

\subsection{LTRAs versus placebo as add-on therapy to tapered doses of ICSs}

A meta-analysis (58) that pooled the results of four trials using LTRAs failed to show a greater reduction of the dose of ICSs in well-controlled patients with asthma treated with LTRAs compared with patients treated with placebo. However, it did show a reduction in withdrawal due to poor asthma control in the groups treated with LTRAs.

Montelukast and placebo were compared in 50 subjects who reduced their ICS dose first to $50 \%$ and then to $25 \%$ for six weeks each (66). Beclomethasone was successfully reduced from $800 \mu \mathrm{g}$ daily to $400 \mu \mathrm{g}$ with no significant differences between the placebo and montelukast groups. Subsequent reduction to $200 \mu \mathrm{g} /$ day resulted in deterioration in lung function in both groups but an increase in night-time symptoms only in the placebo-treated group.

Montelukast and placebo were compared in 191 patients with moderate to severe asthma who were on high doses of an ICS, and showed a reduction in the ICS by $50 \%$ (67). At weeks 8 and 16, the dose was titrated again (reduced again by $50 \%$, maintained or increased). There were no significant differences in the ICS dose between the two groups after the dose was tapered. PEF was slightly but significantly higher in the montelukast group after the reduction in the ICS. There were no significant differences between the two groups in daily activity score, night-time sleep score, $\mathrm{FEV}_{1}$ and vital capacity over the 24-week treatment period. Thus, the addition of LTRAs to ICSs does not result in greater dose reductions of the dose of the ICS, but may provide better asthma control during tapering.

\section{Theophylline}

There are few new studies on theophylline as add-on therapy to ICSs. One study compared theophylline, zafirlukast and formoterol added to budesonide ( $400 \mu \mathrm{g}$ twice daily) over three months in 64 subjects (68). In this small study, the only significant difference was the earlier improvement in lung function and symptoms in the formoterol-treated group; overall, at three months, there was no significant difference between groups.

Another randomized crossover study (30) compared three treatment blocks: beclomethasone (QVAR, 3M Pharmaceuticals, Canada) $100 \mu$ daily alone for two weeks, followed by $400 \mu \mathrm{g}$ daily for the next two weeks; beclomethasone (QVAR) $100 \mu g$ daily followed by $400 \mu g$ daily with the addition of zafirlukast (20 mg twice daily); and beclomethasone (QVAR) $100 \mu$ daily followed by $400 \mu$ daily with the addition of theophylline (200 to $300 \mathrm{mg}$ twice daily). The addition of the LTRA improved asthma control. The addition of LTRA, but not theophylline, to a low dose of ICS had greater effects on the provocative dose of methacholine causing a 20\% decrease in $\mathrm{FEV}_{1}$ (methacholine $\mathrm{PD}_{20}$ ) and exhaled nitric oxide than did a low dose of ICS. The effects were not evident with a medium dose of ICS.

\section{Comparison between LABAs and LTRAs as add-on therapies}

Two large studies compared LTRAs with salmeterol: one study compared zafirlukast (20 mg twice daily) with salmeterol (50 $\mu \mathrm{g}$ twice daily) in 429 patients (69); another compared montelukast ( $10 \mathrm{mg}$ once daily) with salmeterol ( $50 \mu \mathrm{g}$ twice daily) in 948 patients (70). Both studies favoured salmeterol in improving lung function and quality of life, and in reducing symptoms and the need for beta ${ }_{2}$-agonist rescue therapy. The differences in the study using montelukast were small and of questionable clinical significance (70). Neither study had a placebo control. The results were consistent with a previous study (41) in 447 subjects who were not optimally controlled on low doses of ICS. The twice-daily combination of fluticasone $100 \mu \mathrm{g}$ and salmeterol $50 \mu \mathrm{g}$ was superior to a combination of montelukast $10 \mathrm{mg}$ plus twice-daily fluticasone $100 \mu \mathrm{g}$ in improving pulmonary function, symptoms and the exacerbation rate. Ringdal et al (71) compared combination therapy of fluticasone $100 \mu \mathrm{g}$ and salmeterol $50 \mu \mathrm{g}$ (twice daily) with fluticasone ( $100 \mu \mathrm{g}$ twice daily) plus montelukast ( $10 \mathrm{mg}$ once daily) in 725 subjects with moderate asthma. There was a greater improvement in PEF and $\mathrm{FEV}_{1}$ in the salmeterol group, as well as fewer exacerbations.

Another study (72) compared montelukast (10 mg daily) with salmeterol $(50 \mu \mathrm{g}$ twice daily) added to an ICS in 20 subjects for two weeks. Both groups showed significant improvements in asthma control, but only montelukast produced significant effects on adenosine-monophosphate challenge and blood eosinophils, suggesting an anti-inflammatory effect. However, the dose and the type of ICS varied among the subjects.

In conclusion, the addition of a LABA to an ICS seems to be more effective than the addition of an LTRA in achieving asthma control in subjects not optimally controlled on ICSs alone. Additional studies are needed to confirm the superior anti-inflammatory effect of LTRAs over LABAs.

6. Conclusions and recommendations on the use of add-
on therapy in the treatment of asthma
1. LABAs are not recommended as maintenance
monotherapy in asthma (Level I evidence).
2. When, after reassessment of compliance, control of
environment and diagnosis, patients are not optimally
controlled on low doses of ICSs, therapy should be
modified by the addition of a LABA (Level I evi-
dence). Alternatively, addition of LTRAs or increasing
the ICS to a moderate dose may be considered (Level
I evidence). Theophylline may be considered as a third
therapeutic option (Level II evidence).

\section{Suggestions for future research}

1. Long-term studies are needed to evaluate asthma control and remodelling after combined therapies have been used for many years.

2. Additional studies on the steroid-sparing effects of LABAs and LTRAs as add-on therapies to ICSs are needed. 
3. Studies of initial treatment comparing combined therapy with moderate to high doses of ICSs alone in patients with asthma and no previous treatment with ICSs are needed to evaluate the potential benefits of combined therapy over ICSs as first-line therapy in moderate asthma.

4 More studies are needed to compare the asthma control and anti-inflammatory effects of LABAs and LTRAs when used as add-on therapies.

\section{ASTHMA EDUCATION IN ADULTS: AN UPDATE}

\section{Systematic review}

We conducted a systematic review of English language studies of asthma education published after the previous update to the 1999 Canadian Asthma Consensus Guidelines had been completed (73). We used key words such as "asthma" and "education" to perform this search on MEDLINE (PubMed). We also reviewed recent published guidelines $(9,10)$ and relevant Cochrane Reviews (74-76).

The main aspects of education included in this review are the role of education in successful asthma management, the impact of education on asthma control, patient monitoring and self-management plans.

\section{Background}

\subsection{The care gap in asthma management and control}

Several surveys of management of asthma (77-79) and control in Canada have shown that physicians and patients are unaware of the gap between the goal of asthma management, which is disease control (3), and the degree of disease control achieved. Current management of asthma in Canada has failed to achieve adequate control, as it has in other countries. One reason for this is the insufficient education of patients $(78,80)$. Nevertheless, disease control is considered to be achievable, desirable and the main outcome on which therapy should be based $(3,9,10)$.

Asthma remains poorly controlled, even though a large number of patients have a prescriptions for ICSs (79). Many patients do not adequately understand the role of their medications and how to use them $(78,81)$. This may partly explain the poor compliance with maintenance therapy, such as ICS therapy $(82,83)$. Furthermore, a clinical diagnosis of asthma may not have been applied to many persons receiving asthma medications or who consult for what seems to be acute asthma.

It is also apparent that physicians may not assess asthma control consistently or systematically, and that their patients are not made explicitly aware of the purpose of asthma management or the definition of disease control $(77,78)$. If, as seems to be the case, appropriate medication is being prescribed for patients with asthma, the poor outcome and lack of awareness of this poor outcome can be addressed only by education to change physicians' and patients' behaviours.

\subsection{Asthma education: Is it effective and how should it be delivered?}

Previous key studies and analyses have demonstrated that proper self-management and education can result in improved asthma outcomes $(84,85)$. However, comparative analyses of asthma education programs are sometimes difficult because of the different educational methods used, the duration of the program, the nature of the participants and the methods of evaluation. Although asthma education programs have not always been shown to have a measurable outcome of improved asthma control (3), appropriate education designed to change patients' (or physicians') behaviour is the logical approach to encourage compliance with management. It is difficult to improve patient adherence with prescribed medication (83), but this is true for all measures designed to change behaviour and for all chronic diseases. If asthma education programs are to succeed, they must be tailored to the patients' needs, their state of readiness to accept their diagnosis and their role on the management team (86). The difficulty in demonstrating a measurable outcome from patient education and the disagreement between surveys that examine the same material $(75,76)$ indicate that educational programs must be carefully structured, individualized and expertly delivered to be successful.

\subsection{Knowledge and behavioural change}

Providing knowledge to patients does not translate into a change in behaviour (87-89), although it is probably an important initial step. The most effective elements of asthma education include device (eg, inhaler) training, understanding the differences between reliever and controller medications, and providing a disease-monitoring process and a self-management (action) plan $(75,85)$. Education must be presented by persons with strong content knowledge, training and proven ability to induce behavioural change (90). It is probable that most education provided by physicians is quite limited and falls short of this ideal $(91,92)$. Nevertheless, it is essential that physicians participate in the education of their patients, and reinforce and support the role of the asthma educators.

\subsection{Who should be educated?}

Generally, education should have the greatest impact on the most severely affected patients, notably those who use emergency departments and those who require admission to the hospital (9395). This group may also be more susceptible to educational interventions (93-95). In this regard, Côté et al (94) reported on a group of patients recruited during a visit to the emergency department after an asthma exacerbation. In this study, three groups of patients were enrolled: those receiving usual care, those receiving a short educational intervention in the emergency department and those receiving the short educational intervention plus referral to a specialized asthma educator. Only the last group had a significant improvement in asthma outcomes, including a reduction in subsequent visits to the emergency department.

\section{Recent evaluations of asthma education programs}

Recently, additional studies have supported the importance and relevance of asthma education concerning self-management in the overall management of the condition. Our review is, however, restricted to studies including an adult population.

Yilmaz and Akkaya (96) studied, over three years, an educational intervention using video cassettes in the outpatient clinic, patient brochures, inhalation device technique verification, patient education, patient education seminars given 
six times by a chest physician and the availability of a telephone helpline. Fifty-two patients with asthma and significant baseline airway obstruction had been randomly allocated to an educational intervention group $(n=25)$ and a usual care group $(\mathrm{n}=27)$. After three years, the educational group showed a significant improvement in the knowledge score on asthma, improved quality of life and asthma severity scores, and a reduction in the frequency of visits to the emergency department. However, there were no differences between the two groups with regard to admissions. There was a trend toward improved daytime and night-time asthma symptom scores in the educational group.

Couturaud et al (97) reported a randomized, controlled, one-year study in 72 patients. One-half received usual care (control), and one-half was offered education consisting of five individual sessions covering the pathophysiology of asthma, the role of medication and side effects, asthma triggers and their avoidance, detection of an asthma flare-up and a selfmanagement plan based on symptoms and peak flow monitoring. Patients who complied with the action plan in the educated group showed a higher number of symptom-free days than the control group, while the symptom-free days overall were similar in both groups at the end of the study. Changes were similar in both groups, as well as quality of life scores. No difference in asthma knowledge was found between the groups. However, self-management ability scores were significantly higher in the educated group at one year.

Osman et al (98) looked at the influence of a brief selfmanagement program on subsequent admissions for asthma in a 12 -month, randomized, controlled trial in adult patients. The intervention consisted of $1 \mathrm{~h}$ of education supporting a written self-management plan given during hospital admission for acute asthma. The control group received standard care. One month after discharge, the educated group was more likely to report no daytime or night-time symptoms and no activity limitation. Over the one-year follow-up, $17 \%$ of the educated patients and $27 \%$ of the control group were readmitted. This beneficial effect was significant in those with a first admission, and there was a trend toward significant reduction in those with a previous admission. The educated group was more likely to be prescribed ICSs at discharge and oral glucocorticoids, as well as to have a follow-up; however, after adjustments for these differences, the self-management program was still significantly more beneficial in those with first admissions for asthma than in the control group. This study shows the influence of such initial intervention in patients with acute asthma, particularly in those with a firsttime admission for asthma. It also suggests that the educational program was changing medical practice toward better compliance with current asthma guidelines. The authors suggest that this may be the result of the communication between the educator and the physician. They also suggest that we should take the opportunity of patients' admissions to the hospital to educate them on how to better control their asthma.

Put et al (99) evaluated an intervention in patients with mild to moderate asthma who were randomly assigned to an educational program or usual care. The program consisted of a workbook containing information, exercises and homework assignments. Psychoeducation, and behavioural and cognitive techniques were also introduced during six $1 \mathrm{~h}$ individual sessions. Compared with the controls, the program group reported fewer symptoms, better quality of life, reduced negative feelings, increased adherence to the treatment and improvement in cognitive variables. The authors concluded that participation in an individualized program resulted in improvement of asthma morbidity, asthma-related behaviour and knowledge in subjects reporting symptoms and impairment despite adequate medical therapy. However, this study was limited because the period of observation was only three months; ideally, evaluation should be conducted over a longer period.

Thoonen et al (100) compared patients in general practice receiving self-management training with those receiving usual care. The instruction was provided at four educational visits lasting $30 \mathrm{~min}, 20 \mathrm{~min}, 10 \mathrm{~min}$ and $10 \mathrm{~min}$, respectively. During follow-up over two years, those who had been instructed in self-management had significantly better asthma control and lost fewer activity days. The trained group had improved quality of life scores, which were significant in the domain of emotions. An interesting additional outcome was an overall reduction in the dose of ICSs but an increase in the number of courses of oral glucocorticoids used by the trained group of 110 patients. There were no differences in exacerbation rate or spirometric measures between the two groups. In contrast, Ignacio-Garcia et al (101) followed up their earlier study of the impact of asthma education with self-management programs, and found improvement in exacerbation rates, use of oral glucocorticoids and lung function. These improvements were apparent three years after entry into the study, and were attributed to reinforcement visits at three, six, 12, 24 and 36 months after entry to the study.

\section{Environmental control}

A subanalysis of a previous trial by Côté et al (102) revealed an improvement in environmental measures and in the quality of life after a structured educational program. However, those measures were effective mostly against house dust mites; compliance with withdrawal of a domestic animal was poor. More studies should address this problem, because it seems quite difficult to change this behaviour.

\section{Education of adolescents}

Cowie et al (103) reported on 93 patients aged 15 to 20 years who had visited the emergency department for their asthma. They were randomly assigned either to attend an age-specific asthma program, including assessment, education and management by educators, respiratory therapists and physicians, or to have usual care from their regular physicians. After six months, 62 of the patients completed a questionnaire. Participants in both groups showed marked improvement in their asthma control, with a $73 \%$ reduction in the rate of visits to the emergency department, and an improvement in disease-specific quality of life. There were no differences between the two groups, but the educated group faired better in the symptom and emotional domains of the quality of life questionnaire. Thus, significant improvements can be achieved, even though management of asthma seems to be difficult in adolescents. However, it was surprising that the educated group was not significantly better than the control group. In both groups, those completing the 
study could have been the more compliant patients, and contamination may have occurred in the control group. Because these patients were enrolled when they were unstable, regression to the mean possibly explains the changes, and it may have been interesting to have had a longer follow-up period. For example, in the study by Côté et al (94), the reduction in visits to the emergency department in the educational group was only apparent in the second six-month follow-up period.

In another study directed at adolescents, peers provided the education (104). Changes in quality of life measured with the Juniper instrument were apparent in some domains, as well as in some of the groups of educated children compared with controls. There was an overall improvement in quality of life in the educated children, but a significant difference was apparent only in the activities domain and was driven by girls, while boys showed a significant improvement in emotions, although there was no overall difference in that domain.

\section{Health professional and educator training}

Unfortunately, studies on the performance and effectiveness of training programs for asthma educators are few, and there have been none since 1999 to our knowledge. In Canada, certified asthma educators complete an accredited training program and a national examination. All patients with moderate or severe asthma, especially those who suffer severe exacerbations, should be referred to an asthma education program operated by trained educators. Programs are listed on the CNAC Web site at $<$ http://www.cnac.net/english/clinics.html $>$ and on the Quebec Asthma and COPD Network Web site at $<$ http://www.rqam.ca $>$.

\section{Implications for research}

More research on optimal asthma education is necessary, particularly in targeted groups such as those with severe asthma, adolescents and the elderly. Asthma education is an important component of asthma guidelines, and its integration into current care should be promoted in guideline implementation programs (105). Various educational programs have been developed, and the essential components that facilitate behavioural change should be further established. An action plan and regular review seem to be essential, but how to optimize the efficacy and cost effectiveness of those programs remains to be validated in specific populations. Application of these interventions should take into account the resources available, as well as socioeconomic and cultural differences.

Previous studies have shown that the effects of such programs vary with the targeted population. For example, the effects are more pronounced in patients with high asthmarelated morbidity, and probably depend on the type of intervention, training of educators, articulation of various interventions, methods of analysis and duration of study. The design of studies looking at the effectiveness of educational programs should account for these factors, and such information should be provided in publications. The confounding effect of concomitant glucocorticoid treatment should be addressed, and results should be corrected for this factor, although it is not always easy to distinguish the effect of the medication from the educational intervention.
8. Recommendations on asthma education and monitoring

1. Education is an essential component of asthma therapy and should be offered to all patients. Educational interventions may be of particular benefit at the time of hospitalization or a visit to the emergency department (Level I evidence).

2. All patients should have written plans for self-management that include medication adjustment in response to severity or frequency or symptoms and medication requirements for relief of symptoms (Level I evidence).

3. Patient self-monitoring may be effective using either measurement of PEF or monitoring of asthma symptoms (Level I evidence).

4. Measurement of expiratory flow, preferably by spirometry, should be done regularly (Level III evidence).

5. Monitoring PEF may be useful in some patients, particularly in those who poorly perceive their airflow obstruction (Level III evidence).

6. Optimal management of asthma should include regular medical and educational follow-up (Level I evidence).

7. Asthma control criteria should be assessed at each visit (Level IV evidence).

8. Socioeconomic and cultural factors should be taken into account when designing asthma education programs (Level II evidence).

9. Education programs should include an evaluation process on the performance of the program with regard to its established goals (Level III evidence).

\section{Suggestions for future research}

1. What is the effect of the certification of educators on asthma education and clinical outcomes?

2. What are the essential components of an asthma education program?

3. How does one identify high-risk patients for whom education should be emphasized?

4. What is the best way to assess compliance with asthma treatment?

5. How should asthma education be integrated effectively into medical practice?

SPONSORING ORGANIZATION: Canadian Thoracic Society ACKNOWLEDGEMENTS: The prominent participation of Drs Louis-Philippe Boulet, Meyer Balter, Allan Becker, Dennis Bowie, Robert Cowie, Donald Cockcroft, Ken Chapman, Francine Ducharme, Mark Fitzgerald, Donna Hogg, Catherine Lemière and Paul O'Byrne in the writing of this document is acknowledged. The authors also thank Ms Valoree McKay for her very effective administrative support.

COMPETING INTERESTS: Collectively, the physicians on the scientific review panel have on at least one occasion acted as consultants for, received research funds from, received speaker's fees from or received travel assistance from ALTANA Pharma Inc, AstraZeneca Canada Inc, GlaxoSmithKline Inc, Merck Frosst Inc and $3 \mathrm{M}$ Pharmaceuticals.

FUNDING: These guidelines were developed under the auspices of the Canadian Thoracic Society. This process was facilitated by unrestricted educational grants from ALTANA Pharma Inc, AstraZeneca Canada Inc, GlaxoSmithKline Inc, Merck Frosst Inc and $3 \mathrm{M}$ Pharmaceuticals. 


\title{
Mise à jour des recommandations de prise en charge de l'asthme chez l'adulte, édition 2003
}

\author{
Catherine Lemière, M.D. ${ }^{1}$, Tony Bai, M.D. ${ }^{2}$, Meyer Balter, M.D. ${ }^{3}$, Charles Bayliff, D.Pharm. ${ }^{4}$, Allan Becker, M.D. ${ }^{5}$, \\ Louis-Philippe Boulet, M.D. ${ }^{6}$, Dennis Bowie, M.D. ${ }^{7}$, André Cartier, M.D. ${ }^{1}$, Andrew Cave, M.D. ${ }^{8}$, \\ Kenneth Chapman, M.D. ${ }^{3}$, Robert Cowie, M.D. ${ }^{9}$, Stephen Coyle, M.D. ${ }^{5}$, Donald Cockcroft, M.D. ${ }^{10}$, \\ Francine M. Ducharme, M.D. ${ }^{11}$, Pierre Ernst, M.D. ${ }^{11}$, Shelagh Finlayson, E.C.A. ${ }^{12}$, J. Mark FitzGerald, M.D. ${ }^{2}$, \\ Frederick E. Hargreave, M.D. ${ }^{13}$, Donna Hogg M.S., inf. aut., E.C.A. ${ }^{7}$, Alan Kaplan, M.D. ${ }^{14}$, Harold Kim, M.D. ${ }^{15}$, \\ Cheryle Kelm, BPT, M.Sc. ${ }^{9}$, Paul O'Byrne, M.D. ${ }^{13}$, Malcolm Sears, M.D. ${ }^{13}$, Andrea White Markham, inhalothérapeute, E.C.A. ${ }^{16}$, \\ au nom du Groupe canadien de consensus sur l'asthme chez l'adulte de la Société de thoracologie du Canada. \\ ${ }^{1}$ Université de Montréal, Montréal (Québec); ${ }^{2}$ Université de la Colombie Britannique, Vancouver (Colombie \\ Britannique); ${ }^{3}$ Université de Toronto, Toronto (Ontario); ${ }^{4}$ London Health Sciences Centre, London (Ontario); \\ ${ }^{5}$ Université du Manitoba, Winnipeg (Manitoba); ${ }^{6}$ Université Laval, Sainte Foy (Québec); ${ }^{7}$ Université Dalhousie, Halifax \\ (Nouvelle Écosse); ${ }^{8}$ Université de l'Alberta, Edmonton (Alberta); ${ }^{9}$ Université de Calgary, Calgary (Alberta); ${ }^{10}$ Université \\ de la Saskatchewan, Saskatoon (Saskatchewan); ${ }^{11}$ Université McGill, Montréal (Québec); ${ }^{12}$ Toronto (Ontario); \\ ${ }^{13}$ Université McMaster, Hamilton (Ontario); ${ }^{14}$ Richmond Hill (Ontario); ${ }^{15}$ Kitchener Waterloo (Ontario); \\ ${ }^{16}$ William Osler Health Centre, Brampton (Ontario)
}

C Lemière, T Bai, M Balter, et al, au nom du Groupe canadien de consensus sur l'asthme chez l'adulte de la Société de thoracologie du Canada. Mise à jour des recommandations de prise en charge de l'asthme chez l'adulte, édition 2003. Can Respir J 2004;11(Suppl A):19A-30A.

CONTEXTE : Plusieurs séries de recommandations sur le diagnostic et la prise en charge de l'asthme ont été publiées au Canada depuis 15 ans. Depuis la dernière révision des recommandations de la Conférence canadienne de consensus sur l'asthme effectuée en 1999, la publication d'importantes études a rendu nécessaire la mise à jour de ces recommandations.

OBJECTIFS : Examiner la littérature publiée entre janvier 2000 et juin 2003 traitant de la prise en charge de l'asthme chez l'adulte ; évaluer l'influence de ces nouvelles données sur les recommandations publiées en 1999 et mises à jour en 2001; faire état des nouvelles recommandations de prise en charge de l'asthme chez l'adulte.
MÉTHODE : Notre revue de littérature s'est concentrée sur trois thèmes précis pour lesquels les nouvelles données affectaient les recommandations précédentes : le traitement initial, les thérapies d'ajout et l'éducation. En juin 2003, la revue de littérature a été discutée lors d'une réunion tenue sous les auspices de la STC et les recommandations de prise en charge de l'asthme chez l'adulte ont été révisées.

RÉSULTATS : Le présent rapport insiste sur l'importance d'initier la corticothérapie inhalée précocement dans l'asthme léger symptomatique; il souligne les avantages de la thérapie d'ajout, de préférence par les bêta-2 agonistes à longue durée d'action, quand des doses faibles de corticoïdes inhalés sont insuffisantes pour obtenir une maîtrise satisfaisante de l'asthme; et précise le rôle primordial de l'éducation en matière d'asthme.

CONCLUSION : Dans l'ensemble, le présent rapport confirme bon nombre des recommandations de la Conférence canadienne de consensus sur l'asthme publiées en 1999 et fournit des données encore plus probantes à l'appui de plusieurs de ces recommandations.

\section{Historique}

\section{INTRODUCTION}

Les premières recommandations sur le diagnostic et la prise en charge de l'asthme publiées au Canada ont été établies en 1989 par un comité de médecins spécialistes du Canada et d'autres pays travaillant sous la direction de F.E. Hargreave (1). Les réunions tenues par la suite en 1995 (2) et 1998 (3) sous les auspices de la Société de thoracologie du Canada (STC) ont conduit à la révision de ces recommandations. Les recommandations de la Conférence canadienne de consensus sur l'asthme publiées en 1999 (3) ont été largement diffusées et demeurent une référence importante. Ces recommandations ont été révisées en 2001 (4) à la lumière de nouvelles données.
Depuis la dernière révision, la publication d'importantes études a rendu de nouveau nécessaire la révision de plusieurs recommandations. Par ailleurs, il était nécessaire d'aborder plus en détail plusieurs questions spécifiques à l'asthme pédiatrique.

La révision exhaustive des recommandations est un processus complexe qui est superflu pour de nombreuses sections qui sont encore d'actualité. Par conséquent, les membres du comité sur l'asthme de la STC ont convenu de concentrer leurs efforts sur certaines questions spécifiques à l'asthme chez l'adulte, tandis que le comité du consensus pédiatrique du Réseau canadien pour le traitement de l'asthme (RCTA) se penchait sur des questions spécifiques à l'asthme pédiatrique.

Correspondance : Dr Catherine Lemière, Service de pneumologie, Hôpital du Sacré Coeur, 5400, boul. Gouin ouest, Montréal (Québec)

H4J 1C5. Tél. : 514338 2796; fax : 514338 3123, courriel : C-Lemiere@crhsc.umontreal.ca

Tirés à part: Mme Valoree McKay, Société de thoracologie du Canada, 3, rue Raymond, bureau 300, Ottawa (Ontario) K1R 1 A3.

Tél. : 6135696411 ; fax : 6135698860 
TABLEAU 1

Classe de recommandation suivant la valeur probante des données

Niveau I Données fondées sur les résultats d'essais randomisés contrôlés (ou d'une méta-analyse de tels essais) comportant un échantillon de taille suffisante pour garantir un faible risque de résultats faussement positifs ou négatifs.

Niveau II Données fondées sur les résultats d'essais randomisés contrôlés ayant une taille d'échantillon trop faible pour fournir des données de niveau I. Les résultats peuvent indiquer la présence de tendances favorables non significatives sur le plan statistique ou l'absence de telles tendances, et le risque de résultats faussement négatifs est élevé

Niveau III Données fondées sur les résultats d'essais comparatifs sans répartition aléatoire, d'études de cohorte, d'études de cas, d'études cas-témoins ou d'études transversales.

Niveau IV Données fondées sur l'opinion de sources respectées faisant autorité ou de comités d'experts, publiée dans des comptes rendus de conférences de concertation ou des lignes directrices.

Niveau $\vee$ Données fondées sur l'opinion de ceux qui ont rédigé et révisé les recommandations en se fondant sur leur propre expérience, leur connaissance de la littérature pertinente et leurs discussions avec des pairs.

Données tirées de la référence 5 .

TABLEAU 2

Prise en charge globale de l'asthme

\begin{tabular}{|c|c|}
\hline Asthme présumé & Diagnostic différentiel \\
\hline $\begin{array}{l}\text { Confirmer le diagnostic et } \\
\text { évaluer la sévérité au départ }\end{array}$ & $\begin{array}{l}\text { Évaluer les symptômes et la fonction } \\
\text { respiratoire (spirométrie ou débit } \\
\text { expiratoire de pointe) }\end{array}$ \\
\hline $\begin{array}{l}\text { Identifier les déclencheurs } \\
\text { éventuels }\end{array}$ & $\begin{array}{l}\text { Questionner, obtenir des tests d'allergie ou } \\
\text { autres (pour évaluer l'environnement, le } \\
\text { milieu de travail, etc.) }\end{array}$ \\
\hline Initier le traitement & $\begin{array}{l}\text { Prescrire les médicaments nécessaires à la } \\
\text { maîtrise de l'asthme; traiter les conditions } \\
\text { associées (p. ex., rhinite) }\end{array}$ \\
\hline Initier l'éducation établir & $\begin{array}{l}\text { Fournir l'information de base et, si } \\
\text { possible, orienter le patient vers un } \\
\text { éducateur sur l'asthme }\end{array}$ \\
\hline $\begin{array}{l}\text { Cibler les meilleurs résultats } \\
\text { pouvant être atteints }\end{array}$ & $\begin{array}{l}\text { Vérifier les critères de maîtrise de l'asthme, y } \\
\text { compris la fonction respiratoire }\end{array}$ \\
\hline $\begin{array}{l}\text { Établir la posologie } \\
\text { minimale nécessaire à la } \\
\text { maîtrise e de l'asthme }\end{array}$ & $\begin{array}{l}\text { Réduire progressivement la médication en } \\
\text { surveillant le maîtrise de l'asthme }\end{array}$ \\
\hline $\begin{array}{l}\text { Établir le plan d'action en } \\
\text { cas d'exacerbations }\end{array}$ & $\begin{array}{l}\text { Remettre un document écrit ou demander à } \\
\text { un éducateur sur l'asthme de le faire) }\end{array}$ \\
\hline Assurer un suivi régulier & $\begin{array}{l}\text { Vérifier périodiquement les critères de maîtrise } \\
\text { et la fonction respiratoire }\end{array}$ \\
\hline
\end{tabular}

Données tirées de la référence 4.

Les participants des deux comités se sont rencontrés pendant deux jours à Montréal (Québec) les 27 et 28 juin 2003. Le groupe travaillant sur l'asthme chez l'adulte s'est réuni sous les auspices de la STC, l'autre, sous celles du RCTA. Les deux groupes se sont réunis séparément le premier jour puis ont tenu une séance plénière le jour suivant afin de discuter de la diffusion et de la mise en œuvre des recommandations sur la prise en charge de l'asthme.

Le présent document ne traite que des sujets en rapport avec l'asthme de l'adulte; les recommandations relatives à l'enfant feront l'objet d'une publication distincte. Le comité sur l'asthme de la STC a chargé un groupe de spécialistes canadiens de l'asthme de réviser la littérature portant sur des aspects précis de la prise en charge de l'asthme chez l'adulte. Ces spécialistes ont été choisis pour leur travail et leur contribution
TABLEAU 3

\section{Critères d'équilibre de l'asthme}

- Présence de symptômes diurnes moins de 4 jours par semaine

- Présence de symptômes nocturnes moins de 1 nuit par semaine

- Activité physique normale

- Exacerbations asthmatiques légères et peu fréquentes

- Aucun absentéisme dû à l'asthme

- Prise de moins de 4 doses/semaine de bêta ${ }_{2}$ agoniste à action rapide*

- Volume expiratoire maximum dans 1 seconde (VEMS) ou débit expiratoire de pointe (DEP) égaux ou supérieurs à $90 \%$ de leur valeur maximale du patient

- Variabilité diurne du DEP n'excédant pas 10 à $15 \%$

Données tirées de la référence 4. *Outre la prise d'une dose/jour avant l'effort physique.

dans le domaine de l'asthme. Ils ont systématiquement révisé la littérature publiée en langue anglaise entre le $1^{\mathrm{e}}$ janvier 2000 et juin 2003. Le premier jour de la réunion tenue en juin, les membres de ce groupe ont proposé plusieurs recommandations à partir de leur revue de littérature. Ces recommandations ont été discutées au sein du groupe et reformulées jusqu'à ce qu'un consensus ait été atteint

Les membres du groupe ont fondé leurs propositions sur l'examen critique de la littérature et attribué un niveau d'évidence à chaque recommandation selon la qualité des données de la littérature supportant la recommandation (tableau 1) (5). Le document a ensuite circulé parmi les membres et a été révisé selon les commentaires émis le consensus du groupe.

\section{Définition de l'asthme}

La définition de l'asthme est descriptive et n'a pas changé depuis la publication des dernières recommandations (3). L'asthme se caractérise par des symptômes paroxystiques ou persistants tels que la dyspnée, l'oppression thoracique, la respiration sifflante, la production de mucus et la toux, associés à une obstruction bronchique variable et à l'hyperréactivité des voies aériennes à des stimuli endogènes ou exogènes. L'inflammation et ses effets sur la structure des voies aériennes sont considérés comme un des principaux mécanismes responsables de l'apparition et de la persistance de l'asthme.

Cette définition remontant à 1999 est toujours valide. L'inflammation des voies aériennes est la principale caractéristique de l'asthme. Il importe d'acquérir une meilleure compréhension des mécanismes physiopathologiques sousjacents afin d'en améliorer le traitement. De fait, l'amélioration de la compréhension de l'asthme a permis de développer des molécules ciblant directement certains constituants du système immunitaire, comme l'immunoglobuline E (IgE) (6).

\section{Prise en charge globale de l'asthme}

L'optimisation de la prise en charge de l'asthme exige une évaluation adéquate de chaque patient ainsi que l'analyse exhaustive des facteurs environnementaux qui peuvent avoir une influence sur l'asthme du patient (tableau 2) (3). Lorsqu'un clinicien évalue pour la première fois un patient asthmatique, il peut juger de la maîtrise de l'asthme selon les critères publiés antérieurement qui sont toujours valides (tableau 3) (3). L'évaluation de la sévérité de l'asthme est souvent plus ardue et 
TABLEAU 4

Corticostérö̈des pour inhalation : équivalences posologiques proposées

\begin{tabular}{|c|c|c|c|}
\hline \multirow[b]{2}{*}{ Produit } & \multicolumn{3}{|c|}{ Dose quotidienne ( $\mu \mathrm{g} / \mathrm{jour}$ ) } \\
\hline & Faible & Intermédiaire & Élevée \\
\hline DPB, AD et chambre d'espacement & $\leq 500$ & de 501 à 1000 & $>1000$ \\
\hline BUD, Turbuhaler* & $\leq 400$ & de 401 à 800 & $>800$ \\
\hline $\mathrm{PF}, \mathrm{AD}$ et chambre d'espacement & $\leq 250$ & de 251 à 500 & $>500$ \\
\hline PF, Diskus ${ }^{\dagger}$ & $\leq 250$ & de 251 à 500 & $>500$ \\
\hline $\mathrm{DPB}, \mathrm{AD}(\mathrm{HFA})^{\ddagger}$ & $\leq 250$ & de 251 à 500 & $>500$ \\
\hline BUD, nébulisation humide§ & $\leq 1000$ & de 1001 à 2000 & $>2000$ \\
\hline
\end{tabular}

$D P B$ : dipropionate de béclométhasone; $A D$ : aérosol doseur pressurisé; * $B U D$ : budésonide (Turbuhaler; AstraZeneca Inc., Canada) ; ${ }^{\dagger} P F$ : propionate de fluticasone (Diskus; GlaxoSmithKline Canada Inc., Canada); $¥ D P B$ en solution dans l'alcool (Qvar, Produits pharmaceutiques 3M, Canada); HFA : hydrofluoroalcanes; d'autres inhalateurs à base d'HFA (agent propulseur) peuvent délivrer des doses semblables aux doses de DPB libérées au moyen d'un aérosol doseur classique; $\S$ solution de budésonide pour nébulisation humide (AstraZeneca Inc., Canada).

peut n'être possible qu'une fois que l'asthme est maittrisé adéquatement. Cependant, tel que mentionné dans la section sur l'asthme léger, il faut considérer précocement le traitement par corticostéroïdes inhalés, même si le patient se plaint de symptômes d'asthme moins de trois fois par semaine. Les équivalences posologiques relatives aux corticostéroïdes inhalés (CSI) figurant dans ce document (tableau 4) ont été publiées dans les recommandations de 1999 (3).

La présente mise à jour confirme la majorité des recommandations publiées précédemment avec un niveau de confiance supérieur pour certaines de ces recommandations.

Un des thèmes centraux des recommandations publiées précédemment (3) était la notion de continuum de la prise en charge de l'asthme. Nous avons légèrement modifié la figure qui illustre ce continuum de soins afin de tenir compte des nouvelles recommandations (figure 1).

\section{Pharmacothérapie}

De nouvelles molécules ciblant le système immunitaire sont actuellement à l'étude pour le traitement de l'asthme. La Food and Drug Administration a autorisé la commercialisation aux États-Unis d'un anticorps dirigé contre les immunoglobulines $\mathrm{E}$ (IgE), l'omalizumab, mais cet agent n'est pas encore disponible au Canada (6). Le présent document ne traitera que des médicaments disponibles au Canada, dont les corticostéroïdes inhalés (CSI), les bêta-2 agonistes à courte (BACA) et à longue durée d'action (BALA), les antagonistes des récepteurs des leucotriènes (ARLT) et la théophylline. Une mauvaise maitrise de l'asthme n'est pas habituellement due à une inefficacité thérapeutique mais plutôt à l'utilisation sous-optimale des médicaments, à une mauvaise identification des facteurs aggravants, à une mauvaise technique d'inhalation, à l'assainissement insuffisant de l'environnement ou au manque de suivi médical.

\section{Diffusion et mise en œuvre des recommandations}

La diffusion et la mise en œuvre de ces recommandations sont essentielles à l'amélioration de la prise en charge de l'asthme. Un comité composé de représentants des divers organismes impliqués dans le domaine de l'asthme ainsi que des représentants des compagnies pharmaceutiques sera chargé de

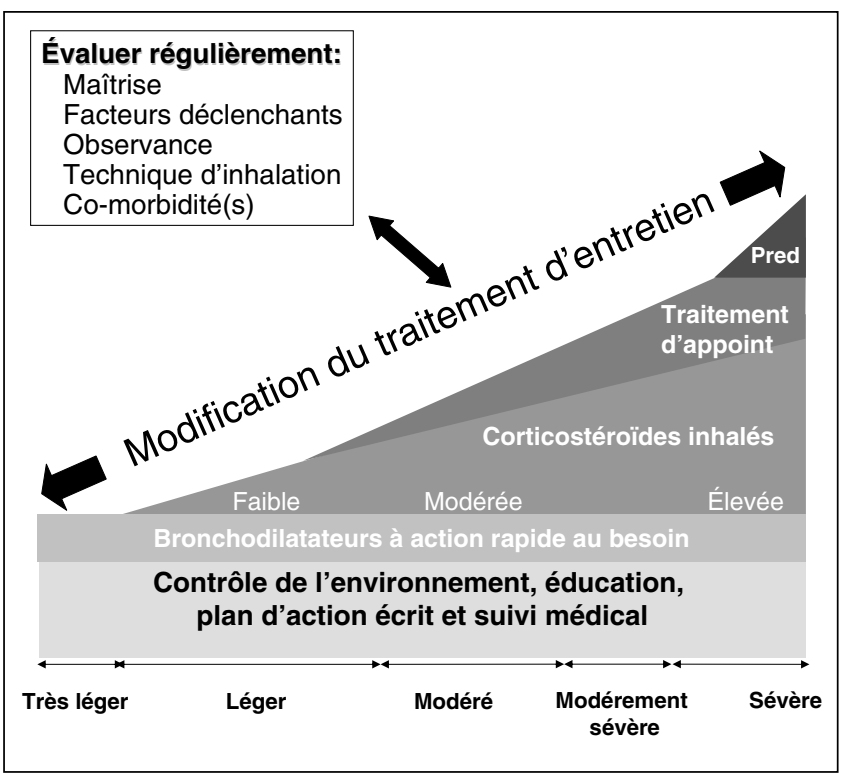

Figure 1) Continuum de la prise en charge de l'asthme. L'asthme très léger se traite avec la prise au besoin de bronchodilateurs à action rapide. La prise de CSI peut constituer le premier traitement d'entretien, même si les symptômes d'asthme sont moins fréquents que trois fois par semaine. Si le patient ne peut pas ou ne veut pas prendre de CSI, la prise d'un ARLT peut être une solution de rechange, même si elle est moins efficace que celle de CSI à faible dose. Si l'emploi de CSI à faible dose ne permet pas de contrôler l'asthme de manière satisfaisante, il faut considérer l'ajout d'un autre médicament. L'ajout d'un BALA doit être considéré comme premier choix. On peut en deuxième lieu considérer l'ajout d' un ARLT ou l'augmentation de la dose de CSI à une dose modérée. La troisième option à considérer est l'ajout de théophylline. L'asthme sévère peut exiger l'ajout de prednisone (Pred). La maitrise de l'asthme doit être évalué à chaque consultation, et le traitement d'entretien, modifié au besoin. Toute modification de la pharmacothérapie doit être considérée comme un essai thérapeutique, et son efficacité, réévaluée après un délai raisonnable. Une fois l'asthme adéquatement maitrisé, il faut viser la dose minimale nécessaire pour conserver la maitrise

la diffusion et de la mise en place de ces recommandations conjointement avec celles émises pour l'asthme pédiatrique.

\section{Conclusions}

Les recommandations exposées dans ce document doivent être considérées comme un guide pour la prise en charge de l'asthme basé sur les données récentes de la littérature. Cependant, chaque patient souffrant d'asthme doit être évalué individuellement et objectivement en tenant compte de variables précises, dont les symptômes, la fonction respiratoire et la survenue d'effets indésirables liés au traitement. La maîtrise de l'asthme et son traitement d'entretien doivent être ré-évalués à chaque consultation médicale. Toute modification de la pharmacothérapie devrait faire l'objet d'une période d'essai, et son efficacité, devrait être réévaluée après un délai raisonnable.

Les autres outils présentement à l'étude, comme l'expectoration induite (7) ou la mesure de du monoxyde d'azote expiré (8), pourraient aider à mieux caractériser le degré d'inflammation des voies aériennes et à améliorer la prise en charge de l'asthme. 


\section{LE RÔLE DES CSI DANS LE TRAITEMENT INITIAL DE L'ASTHME}

\section{Historique}

La nature inflammatoire de l'asthme et l'importance du traitement anti-inflammatoire sont bien établies dans toutes les recommandations sur l'asthme $(3,9,10)$. Plusieurs études portant sur des cas d'asthme mal contrôlés malgré l'emploi de CSI, on démontré que l'ajout d'un BALA était plus efficace que de doubler la dose de CSI $(11,12)$. Cependant trois questions importantes restent à élucider :

1. Quel est le meilleur moment pour débuter la corticothérapie inhalée dans l'asthme léger?

2. Quels patients bénéficieraient davantage d'un traitement d'association plutôt que de l'emploi de CSI seuls?

3. Est-il préférable d'employer des CSI ou des ARLT en première intention dans l'asthme léger?

Nous avons revu les données supportant l'utilisation des CSI dans l'asthme léger et fait une évaluation critique des données relatives à ces trois questions. Cette brève revue systématique s'est limitée aux études publiées depuis 2000. Nous avons également demandé à toutes les compagnies pharmaceutiques qui distribuent des médicaments contre l'asthme de nous fournir les articles non publiés ainsi que leurs données internes des trois dernières années.

\section{Utilisation des CSI dans l'asthme léger}

De nombreuses études ont examiné l'utilité des CSI dans le traitement de l'asthme léger ou modéré. Deux revues systématiques de la littérature $(13,14)$ ont été publiés antérieurement à notre période de révision de la littérature. Le premier (13) portait sur 52 études auxquelles avaient participé 3459 sujets. La béclométhasone s'était révélée significativement supérieure au placebo quant à l'amélioration du VEMS (différence moyenne pondérée [DMP] de $340 \mathrm{~mL}$; intervalle de confiance [IC] de $95 \%$ de 190 à $500 \mathrm{~mL}$ ), du VEMS (pourcentage prévu; DMP de $6 \%$; IC de $95 \%$ de 0,4 à $11,5 \%$ ) et du DEP matinal (DMP de $50 \mathrm{~L} / \mathrm{min}$; IC de $95 \%$ de 8 à $92 \mathrm{~L} / \mathrm{min}$ ) dans toutes les études contre placebo. Outre la réduction de l'emploi des BACA, les sujets qui utilisaient des CSI étaient moins à risque d'être retirés de l'étude en raison d'une exacerbation de leur asthme (risque relatif [RR] de 0,54, IC de $95 \%$ de 0,15 à 0,43 ) que ceux qui recevaient le placebo. D'autres analyses systématiques (13-16) ont confirmé le rôle primordial des CSI dans l'asthme et ont dans l'ensemble indiqué que l'augmentation des doses de CSI n'offrait qu'un bénéfice minime par rapport aux faibles doses dans l'asthme léger. La conclusion globale de ces études est que la prise de CSI constitue l'intervention optimale en cas d'asthme léger persistant.

\section{Utilisation des CSI précocement dans l'asthme léger}

Malgré l'importance des données en faveur de l'utilisation des CSI, la justification de l'emploi des CSI précocement dans l'asthme léger persistant n'était pas claire jusqu'ici et n'avait pas toujours convaincu les médecins de prescrire ces agents. Dans le cadre de l'étude START (17), large étude prospective visant à démontrer l'utilité de la prescription précoce des CSI dans l'asthme léger, 7241 patients ont reçu du budésonide (adultes, $400 \mu \mathrm{g} /$ jour; enfants, $200 \mu \mathrm{g} /$ jour) ou un placebo en inhalation suivant une répartition aléatoire. Le VEMS initial était de $86,6 \%$, et de $96,2 \%$ après bronchodilatateur. Plus de $91 \%$ des patients avaient eu des symptômes d'asthme pendant un jour ou plus au cours des 2 semaines précédant la randomisation et n'avaient jamais pris de CSI auparavant. La mise en route précoce d'un traitement par CSI s'est traduite par une plus grande réduction des symptômes d'asthme mais surtout par une baisse significative de $44 \%$ de la fréquence d'exacerbation grave (RR de 0,56; IC de $95 \%$ de 0,45 à 0,71; $\mathrm{P}<0,0001)$. On a également remarqué une augmentation du VEMS initial $(1,48 \%$ après 1 an; $\mathrm{P}<0,0001 ; 0,88 \%$ après 3 ans; $\mathrm{P}<0,0001)$. La probabilité d'avoir besoin d'un traitement anti-inflammatoire supplémentaire était également moins élevée chez les patients qui recevaient les CSI.

\section{CSI comparé au traitement combiné (CSI+ BALA) en traitement initial de l'asthme léger}

L'utilisation combinée d'un BALA et de CSI est bien établie dans la prise en charge de l'asthme modéré ou grave (18). Le rôle du traitement combiné est moins clair en cas d'asthme léger ou modéré. Peu d'études ont porté directement sur ce point. O'Byrne et al (19) ont randomisé 698 patients (groupe A) à recevoir soit une faible dose de CSI $(100 \mu \mathrm{g}$ de budésonide, 2 f.p.j.) combinée à un BALA ( $6 \mu$ g de formotérol, 2 f.p.j.) soit un CSI seul (100 $\mu$ g de budésonide, 2 f.p.j.) soit un placebo. L'ajout de $6 \mu \mathrm{gg}$ de formotérol au CSI a entraîné une amélioration de la fonction respiratoire mais n'a pas amené de bénéfice additionnel par rapport au CSI seul. Même dans cette population atteinte d'asthme léger, l'emploi du CSI a entraîné une diminution de fréquence d'exacerbations graves de $68 \%$ par rapport au placebo. Sur les 1272 patients qui avaient déjà reçu des CSI (groupe B) et dont la fonction respiratoire initiale était un peu plus basse (VEMS moyen égal à $86 \%$ du pourcentage prévu au lieu de $90 \%$ ), l'ajout du formotérol au CSI s'est révélé non seulement plus efficace que la prise du placebo mais également plus que le double de la dose de CSI.

Une petite étude ouverte pré-post, non randomisée a évalué le salmétérol et le fluticasone, chez 127 patients atteints d'asthme léger ou modéré pendant 4 semaines. Le VEMS moyen de départ s'établissait à 2,68 \pm 0,7 L (82,2\% de la valeur prévue) (20). On nota une amélioration significative de la maîtrise de l'asthme chez ces patients, mais le devis de cette étude (petite, ouverte, non randomisée) ne nous permettait pas d'utiliser cette étude pour formuler des recommandations.

\section{CSI comparé aux ARLT dans le traitement d'entretien initial de l'asthme léger}

Les CSI sont habituellement recommandés dans le traitement d'entretien initial de l'asthme léger. Les ARLT peuvent constituer une solution de rechange aux CSI. Une revue systématique récente de la littérature, a comparé les effets des CSI (400 $\mu \mathrm{g}$ de béclométhasone ou autre CSI en dose équivalente) à ceux des ARLT dans l'asthme léger (21). L'auteur avait identifié 13 essais (portant tous sur des adultes à l'exception d'un seul). Chez les patients qui recevaient un ARLT, la probabilité d'exacerbation de l'asthme exigeant une corticothérapie orale était de 60 \% plus élevée que chez ceux qui 
prenaient un CSI (RR de 1,6; IC à $95 \%$ de 1,2 à 2,2). De plus, les patients qui prenaient des CSI avaient moins de symptômes et une meilleure fonction respiratoire. Enfin, la probabilité d'un retrait des études en raison d'une maîtrise inadéquate de l'asthme était beaucoup plus grande chez les sujets qui recevaient un ARLT (RR de 2,5; IC de $95 \%$ de 1,8 à 3,5).

\section{Autres publications}

Notre revue de la littérature a permis d'identifier 26 autres articles (22-47) publiés au cours des trois dernières années. La plupart de ces articles ont été exclus parce qu'ils étaient pour la plupart déjà été intégrés aux revues systématiques récentes ou qu'ils traitaient d'études portant sur les avantages relatifs de l'association BALA CSI plutôt que sur l'emploi des CSI tôt dans le cours de l'asthme (notre question première). Nous avons également écarté les études dont les participants prenaient déjà des CSI ou qui ne comportaient pas de comparaison avec un placebo.

\section{Recommandations}

Nos recommandations sont basées sur la définition suivante de l'asthme léger : symptômes d'asthme intermittents, nécessitant la prise d'un beta-2 agonistes d'action courte ou rapide au moins deux fois par semaine pour contrôler les symptômes, avec un VEMS supérieur à $85 \%$ de la valeur prédite.

1. Les CSI devraient être débutés précocement dans le traitement d'entretien initial de l'asthme symptomatique (Niveau I).

2. Aucune évidence actuelle ne supporte l'utilisation de thérapies combinées (CSI+BALA) comme traitement de première ligne chez les patients avec un asthme léger n'ayant pas reçu antérieurement de CSI (Niveau I)

3. Les ARLT peuvent constituer une alternative pour les patients qui ne peuvent pas ou ne veulent pas utiliser des CSI (Niveau I). Cependant, en monothérapie, les ARLT sont moins efficaces que les CSI à faible dose (Niveau I).

4. Les doses de CSI recommandées dans l'asthme léger sont sécuritaires (Niveau III).

\section{Pistes de recherche}

1. Quelle est la dose minimale efficace de CSI dans le traitement de l'asthme?

2. L'emploi régulier de CSI peut-il modifier l'évolution naturelle de l'asthme?

3. Peut-on améliorer la prise en charge de l'asthme en tenant compte l'inflammation des voies aériennes?

4. Une proportion importante de patients avec asthme léger présente des exacerbations sévères. Il faut définir la stratégie optimale pour la prévention de ces exacerbations d'asthme qui débutent par une aggravation précoce des symptômes et finissent par une exacerbation sévère.

\section{Stratégies de mise en œuvre}

Le message clé à transmettre aux médecins de famille est que les données appuyant la mise en route rapide du traitement par les CSI en cas d'asthme léger sont excellentes. Rien ne supporte présentement l'emploi en première intention d'un traitement combiné (CSI+BALA) en cas d'asthme léger. La sensibilisation du médecin et du patient devrait être axée sur les résultats d'études cliniques menées récemment qui ont confirmé l'utilité des CSI tôt dans l'asthme. L'éducation du patient doit être axée sur les bienfaits offerts par les CSI et procurer l'assurance que la prise de ces agents aux doses nécessaires à la maîtrise de l'asthme léger est sans danger.

\section{LES THÉRAPIES D’APPOINT DANS L'ASTHME}

\section{Introduction}

Bien que les CSI demeurent la pierre angulaire du traitement d'entretien de l'asthme, il existe au moins trois autres classes de produits qui se sont révélés utiles dans en traitement d'ajout de l'asthme inadéquatement maîtrisé malgré l'emploi des CSI : les BALA inhalés (11), les ARLT oraux (48) et la théophylline orale (49). Chaque classe thérapeutique a démontré sa capacité à améliorer a maîtrise de l'asthme ou à réduire la dose de CSI.

Nous avons cherché à évaluer et à comparer l'efficacité de ces médicaments quand ils sont ajoutés aux CSI ainsi que leur effet sur la réduction des doses de CSI.

La revue systématique d'essais cliniques publiés en anglais depuis la dernière mise à jour des recommandations sur l'asthme, entre le 1 janvier 2000 et juin 2003, a été effectué dans la base de données PubMed à partir des mots clés « advair », « antileukotrienes », « formoterol », « long-acting beta $_{2}$-agonists », " montelukast », « salmeterol », « seretide », « serevent », « oxeze », « oxis », « symbicort », «theophylline » et «zafirlukast». Nous avons communiqué avec GlaxoSmithKline, AstraZeneca et Merck Frosst afin d'obtenir les données d'études non publiées portant sur leurs produits contre l'asthme. Nous avons également interrogé la librairie Cochrane.

Comme on pouvait s'y attendre, la plupart des études ont été commanditées par des compagnies pharmaceutiques. Il a donc fallu tenir compte d'un possible biais dans la conception des études, l'interprétation des résultats et la publication des rapports. De plus, les médicaments peu coûteux et anciens comme la théophylline peuvent avoir été désavantagés parce qu'il est peu probable qu'une compagnie pharmaceutique engage des dépenses pour étudier ces agents dans le traitement d'ajout dans une large étude; de fait, très peu d'articles portaient sur la théophylline ont été publiés récemment.

\section{Bêta-2 agonistes à longue durée d'action}

Depuis plusieurs années, il a été démontré que les BALA administrés avec des CSI étaient sûrs et efficaces, et qu'ils permettaient d'améliorer la maîtrise de l'asthme lorsque celui-ci était mal maîtrisé malgré des doses modérées de CSI (12). L'utilisation des BALA en monothérapie a également été évaluée. $(50,51)$ Des études récentes ont examiné la combinaison BALA et faible dose de CSI comparé à une plus forte dose de CSI en monothérapie; d'autres ont évalué la possibilité de réduire la dose de CSI en ajoutant un BALA au traitement.

\subsection{Utilisation des BALA en monothérapie dans le traitement de l'asthme}

L'utilisation de salmétérol en monothérapie ne permet pas d'obtenir une maîtrise satisfaisante de l'asthme. Dans le cadre 
d'une étude comparative randomisée à double insu, avec groupes parallèles, la triamcinolone $(400 \mu \mathrm{g}, 2$ f.p.j.) a été comparée au salmétérol (42 $\mu \mathrm{g}, 2$ f.p.j.) et à un placebo (50). Malgré une réduction acceptable des symptômes et une amélioration raisonnable de la fonction respiratoire, le groupe recevant salmétérol en monothérapie a présenté davantage d'exacerbations asthmatiques et davantage d'échecs de traitement. Lors d'une autre étude qui portait sur la possibilité de réduire la consommation de CSI en ajoutant un BALA au traitement, on a observé un plus grand nombre d'exacerbations asthmatiques (46,3\% des patients) chez les sujets qui avaient complètement cessé la triamcinolone que chez ceux qui prenaient à la fois de la triamcinolone (400 $\mu$ g, 2 f.p.j.) et du salmétérol (13,7\% des patients) (51). L'analyse préliminaire des résultats de l'étude SMART récemment interrompue, a confirmé ces observations, en constatant que l'emploi du salmétérol seul était associé à une prévalence significativement plus élevée d'effets indésirables, dont le décès, que la prise du placebo parmi les 26000 participants (près de la moitié) qui ne prenaient pas de CSI (52).

\subsection{BALA comparés au placebo en tant que traitement d'ajout aux CSI}

Plusieurs études clés effectuées chez des adultes ont permis de constater qu'il est nettement préférable d'ajouter un BALA à un CSI à doses modérées que de doubler la dose de CSI pour obtenir une meilleure maîtrise de l'asthme $(11,12,18,53)$. Plus récemment, Zetterstrom et ses collègues (54) ont comparé l'inhalation de budésonide $(200 \mu \mathrm{g})$ et de formotérol $(6 \mu \mathrm{g})$ réunis dans un même inhalateur, à ces 2 agents pris séparément au moyen de 2 inhalateurs distincts et au budésonide seul ( $200 \mu g, 2$ bouffées, 2 f.p.j.) chez 362 sujets. Les deux formes d'association médicamenteuse se sont révélées supérieures au CSI seul quant aux symptômes, à la fonction respiratoire et à la maîtrise de l'asthme. D'Urzo et ses collègues (55) ont comparé le salmétérol à un placebo dans le traitement d'ajout en milieu non spécialisé chez 712 sujets asthmatiques qui prenaient des CSI. Ils ont observé une diminution des symptômes et une augmentation des débits expiratoires, mais aucune différence quant à la fréquence d'exacerbations.

\subsection{BALA en traitement d'ajout aux CSI à faibles doses comparé au doublement des doses de CSI}

Heyneman et ses collègues (56) ont analysé les résultats de quatre essais visant à comparer l'association salmétérolfluticasone faiblement dosé à la prise de fluticasone seul. Une seule de ces études comportait une comparaison avec un placebo. Cette revue incluait l'étude menée par Matz et ses collègues (39), qui réunit en fait deux essais. Dans trois de ces quatre études, on a constaté que pour la plupart des paramètres considérés, l'association salmétérol-fluticasone $(50 \mu \mathrm{g}$ et $100 \mu \mathrm{g})$ était supérieure à l'emploi du fluticasone seul $(250 \mu \mathrm{g}$, 2 f.p.j.). Dans une seule étude, la fréquence d'exacerbation était plus faible chez les participants qui recevaient cette association (39). Une seule étude comparait l'emploi de doses faibles ou modérées de fluticasone (de 100 à $250 \mu \mathrm{g}, 2$ f.p.j.) en association avec le salmétérol à celui de doses modérées ou élevées de fluticasone seul (de 250 à $500 \mu g, 2$ f.p.j.) (42). Dans cette étude, l'association fluticasone-salmétérol s'est révélée légèrement supérieure à l'emploi du CSI seul (42). Les auteurs ont conclu que l'association salmétérol-fluticasone faiblement dosé est supérieure à l'emploi du fluticasone seul à doses modérées. Dans à une l'analyse à posteriori de ces deux études, Matz et ses collègues (39) ont utilisé un large échantillon de patients (925 sujets) pour mettre en évidence une diminution du nombre d'exacerbations avec la prise biquotidienne de $100 \mu \mathrm{g}$ de fluticasone et de $50 \mu \mathrm{g}$ de salmétérol qu'avec celle de fluticasone seul (250 $\mu \mathrm{g}, 2$ f.p.j.) comme observé pendant l'étude FACET (11), De fait, 41 patients (8,8 \%) sous fluticasone et salmétérol ont présenté 47 exacerbations asthmatiques avec alors que 63 sujets $(13,8 \%)$ du groupe qui recevait une plus forte dose de fluticasone seul ont présenté 75 exacerbations $(P=0,017)$.

\subsection{BALA comparé au placebo en traitement d'ajout pendant la réduction de dose des CSI}

Un BALA peut être associé à un CSI afin de réduire la dose de CSI administrée. Lemanske et ses collègues (51) ont étudié

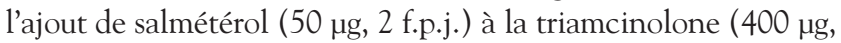
2 f.p.j.) chez 154 sujets; la dose de triamcinolone a été ensuite réduite de $50 \%$ chez la moitié des membres de ce groupe, puis cessée par la suite. Un petit nombre de participants $(\mathrm{n}=21)$ ont reçu un placebo. La variable principale considérée était l'« échec du traitement ». L'échec de traitement est survenue, trois fois plus fréquemment mais non de façon significative, après la réduction de moitié de la dose de triamcinolone à la $8^{\mathrm{e}}$ semaine de traitement. En revanche, à la $16^{\mathrm{e}}$ semaine, le nombre d'échecs au traitement était très significativement plus fréquent dans le groupe ayant cessé le CSI que dans le groupe avec CSI (46 et $14 \%$ respectivement). Les auteurs ont conclu que l'ajout d'un BALA permettait de réduire de moitié la dose de CSI. Les critiques de cette étude ont avancé que dans le groupe où la dose de CSI avait été réduite de moitié, le nombre d'échecs du traitement aurait pu augmenter significativement si l'étude avait duré plus longtemps et si l'échantillon avait été de plus grande taille (57).

Price et ses collègues (43) ont étudié 663 sujets ont reçu du budésonide $(400 \mu \mathrm{g}, 2$ f.p.j.) en association avec soit un placebo ou du formotérol (12 $\mu$ g, 2 f.p.j.) pendant 4 semaines suivant une répartition aléatoire, puis 505 participants chez qui l'asthme était bien maîtrisé ont diminué la dose de budésonide (400 $\mu g, 1$ f.p.j.) en association avec soit un placebo ou du formotérol (12 $\mu$ g, 2 f.p.j.) suivant une nouvelle répartition aléatoire. L'emploi du formotérol s'est traduit par l'atteinte plus rapide de la maîtrise de l'asthme au cours de ces 4 semaines. Pendant les 6 mois qui ont suivi, l'association formotérol-budésonide à faible dose s'est révélée plus efficace que la prise de faibles doses de budésonide seul quant à tous les paramètres considérés, y compris le délai de survenue de la première exacerbation légère de l'asthme. Cependant, l'exclusion des sujets chez qui l'asthme n'était pas bien contrôlé malgré l'emploi associé de budésonide et de formotérol peut constituer un biais de sélection.

Busse et ses collègues (26) ont étudié 760 sujets sous fluticasone ( $250 \mu g, 2$ f.p.j.). Ils ont ensuite diminué la dose de fluticasone à $100 \mu \mathrm{g}, 2$ f.p.j. pendant une seconde période (5 à 28 j). Seuls les sujets dont l'asthme n'était pas contrôlé adéquatement malgré la prise biquotidienne de $100 \mu g$ de 
fluticasone étaient admissibles à cet essai. Les sujets ont ensuite repris fluticasone $(250 \mu \mathrm{g}, 2$ f.p.j. $)$ pour les restabiliser. Par la suite suivant une répartition aléatoire, 277 patients ont poursuivi le même traitement tandis que 281 sujets recevaient le fluticasone $(100 \mu \mathrm{g})$ en association avec le salmétérol $(50 \mu \mathrm{g}) 2$ f.p.j. Dans chaque groupe, la proportion de sujets qui ont participé jusqu'au bout sans évidence d'exacerbation asthmatique était la même; le nombre total d'exacerbations asthmatiques, également. Les DEP étaient plus élevés et le recours au salbutamol plus rare dans le groupe qui recevait le salmétérol. Les auteurs ont conclu que l'ajout du salmétérol avait permis de réduire la dose de fluticasone de $60 \%$. Cependant, la dose de fluticasone n'a été réduite qu'une seule fois au cours de cet essai, et il se peut que l'on ait surévalué l'importance de la réduction de la dose de CSI. En effet, la prise de $350 \mu \mathrm{g}$ de fluticasone au lieu de $500 \mu \mathrm{g}$ pourrait avoir suffi à l'atteinte d'une maîtrise satisfaisant de l'asthme dans le groupe qui ne recevait pas de BALA.

Il semble donc que l'emploi des BALA permette de réduire la dose de CSI, mais il faudra mener d'autres études pour établir l'ordre de grandeur de l'effet épargneur des stéroïdes et la portée clinique de cet effet. Dans tous les cas, il faut continuer d'administrer une dose appropriée de CSI afin d'éviter la survenue d'exacerbations asthmatiques.

\section{Antagonistes des récepteurs des leucotriènes}

\subsection{ARLT comparé au placebo en tant que traitement d' ajout aux CSI}

Une méta analyse récente (58) a combiné les essais randomisés qui comparaient l'emploi d'ARLTs ou d'un placebo en thérapie d'ajout aux CSI. L'administration de montélukast était associée à une amélioration légère mais significative du DEP, une réduction de la consommation de BACA et du le nombre d' éosinophiles comparé au placebo. Cependant, l'utilisation des LTRA n'a pas entraîné de réduction plus importante du nombre d'exacerbations que celle du placebo. Seule l'administration de doses plus élevées que les doses recommandées de pranlukast (450 mg, 2 f.p.j.) ou de zafirlukast (80 mg, 2 f.p.j.) a occasionné une diminution des exacerbations.

Montélukast a été comparé au placebo chez 100 sujets atteints d'asthme mal maîtrisé qui prenaient en général de fortes doses de CSI et qui recevaient déjà pour la plupart un ou deux agents d'ajout (59). Dans cette étude conçue pour simuler une situation réelle d'asthme mal maîtrisé, l'effet du montélukast était similaire à celle du placebo. Cependant, une critique sévère de l'étude a dénoncé des biais en défaveur de l'emploi de l'ARLT dans un groupe recevant déjà un lourd traitement anti-asthmatique(60,61). Comme il a déjà été décrit (62), les deux principales raisons expliquant une mauvaise maîtrise de l'asthme en dépit d'un traitement anti-asthmatique maximal sont la nonobservance au traitement et la possibilité que plusieurs symptômes, voire tous les symptômes, soient imputables à une autre cause que l'asthme (61) .

Une étude randomisée en chassé croisé à double aveugle (63), a comparé fluticasone (100 $\mu$, 2 f.p.j.) associé à un placebo ou au montélukast (10 mg/jour) chez 28 sujets. Aucune différence significative entre ces deux traitements n’a été démontrée quant aux symptômes, à la fonction respiratoire et aux marqueurs de l'inflammation. Par ailleurs, une étude multicentrique en double aveugle (64) a visé à comparer l'ajout de montélukast ou d'un placebo chez des patients dont l'asthme n'était pas maîtrisé de façon satisfaisante malgré l'emploi de CSI (de 400 à $1600 \mu \mathrm{g} /$ jour). Les auteurs ont constaté une réduction plus importante du nombre de jours sans symptômes d'asthme et de la consommation de BACA ainsi qu'une plus grande amélioration du DEP dans le groupe traité que le groupe témoin. Par conséquent, l'ajout de montélukast aux CSI semble entraîner une légère amélioration de l'équilibre de l'asthme quand la prise de CSI seuls ne permet pas d'atteindre un équilibre satisfaisant.

\subsection{ARLT en tant que traitement d'ajout aux CSI comparé au doublement des doses de CSI}

D'après une méta-analyse récente (58), seulement deux essais dont les résultats n'ont pas été publiés ont comporté une comparaison entre le traitement d'ajout avec zafirlukast et le doublement des doses de CSI. On n'a pas observé de différence significative en ce qui a trait au risque d'exacerbation de l'asthme, au DEP, aux symptômes et à la consommation de BACA entre le groupe qui recevait le zafirlukast en doses 4 fois plus fortes que la dose recommandée et celui qui prenait les CSI à fortes doses. Cependant, l'étude n'avait pas la puissance statistique nécessaire pour que l'on puisse conclure à l'équivalence des deux démarches thérapeutiques.

L'emploi associé du montélukast (10 mg) et du budésonide ( $800 \mu \mathrm{g} /$ jour) a semblé aussi efficace que celui du budésonide seul (1600 $\mu \mathrm{g} /$ jour $)$ chez 889 sujets qui étaient encore symptomatiques malgré la prise de budésonide ( $800 \mu \mathrm{g} / \mathrm{jour})$ pendant 30 jours (65). L'amélioration du DEP, de la qualité de la vie et du taux sanguin d'éosinophiles se comparait dans les deux groupes. L'effet des traitements sur la fréquence d'exacerbation était également comparable. Cependant, il faudrait étendre cet essai à plusieurs milliers de patients pour prouver que les démarches comparées s'équivalent. Par conséquent, bien que l'association d'un ARLT à une dose modérée de CSI semble aussi efficace que le fait de doubler la dose de CSI, l'équivalence de ces deux démarches n'a pas encore été établie.

\subsection{ARLT comparé au placebo comme traitement d'ajout lors de la réduction de dose des CSI}

D'après la méta-analyse (58) des résultats regroupés de quatre essais portant sur des ARLT chez des patients dont l'asthme était bien maîtrisé, l'ajout de ces agents à la prise de CSI n'a pas entraîné de réduction plus importante de la dose de CSI que celui d'un placebo. Cependant, le nombre de retraits de l'étude motivés par la maîtrise insatisfaisante de l'asthme s'est révélé plus bas dans les groupes qui recevaient un ARLT.

Le montélukast a été comparé à un placebo chez 50 patients dont la dose initiale de béclométhasone a été réduite de $50 \%$ pendant 6 semaines, puis de $50 \%$ encore pendant 6 autres semaines (66). On a réussi à diminuer la dose du CSI de 800 à $400 \mu \mathrm{g} /$ jour sans observer de différence significative entre les groupes témoin et traité. Le passage à la dose de $200 \mu \mathrm{g} / \mathrm{jour}$ s'est toutefois traduit par une détérioration de la fonction 
respiratoire dans les deux groupes mais la fréquence des symptômes nocturnes n'a augmenté que dans le groupe témoin.

Chez 191 patients atteints d'asthme modéré ou sévère qui prenaient de fortes doses de CSI, l'ajout du montélukast ou d'un placebo a permis de réduire la dose de CSI de $50 \%$ (67). À la $8^{\mathrm{e}}$ et à la $16^{\mathrm{e}}$ semaines, la dose de CSI a été modifiée (autre réduction de moitié, pas de changement ou augmentation) La dose de CSI administrée dans les deux groupes était similaire à la fin de l'étude. Le DEP était légèrement mais significativement plus élevé dans le groupe traité par montelukast que le groupe témoin après la réduction de la dose de CSI. Aucune différence significative n'a été observée entre les deux groupes quant au score des activités quotidiennes, du sommeil nocturne, au VEMS et à la capacité vitale pendant la période de traitement de 24 semaines. Par conséquent, l'ajout d'un ARLT au traitement par les CSI ne permet pas de réduire davantage la dose de CSI, mais peut occasionner une meilleure maîtrise de l'asthme lors de la réduction graduelle de la dose de CSI.

\section{Théophylline}

Peu d'études ont porté récemment sur l'emploi de la théophylline en tant que traitement d'ajout aux CSI. Une étude de 3 mois comportait une comparaison entre la théophylline, le zafirlukast et le formotérol associés au budésonide (400 $\mathrm{gg}$, 2 f.p.j.) chez 64 sujets (68). Pendant cette petite étude la seule différence significative était l'amélioration plus rapide de la fonction respiratoire et des symptômes dans le groupe qui recevait le formotérol. En revanche, au bout de trois mois, il n'y avait aucune différence significative entre les groupes.

Une autre étude randomisée en chassé croisé (30) visait à comparer les trois traitements suivant béclométhasone $100 \mu \mathrm{g}$ quotidiennement (Qvar, Produits pharmaceutiques $3 \mathrm{M}$, Canada) seul pendant 2 semaines, suivie de $400 \mu \mathrm{g}$ pendant les 2 semaines suivantes; de béclométhasone $100 \mu \mathrm{g}$ quotidiennement, puis $400 \mu \mathrm{g}$, en association avec du zafirlukast (20 mg, 2 f.p.j.); de béclométhasone $100 \mu g$ quotidiennement, puis de $400 \mu \mathrm{g}$, en association avec de la théophylline (de 200 à 300 mg, 2 f.p.j.). L'ajout de l'ARLT a entraîné l'amélioration de la maîtrise de l'asthme. L'ajout de l'ARLT, mais pas celle de la théophylline, au CSI à faible dose a eu plus d'effet sur la dose de la provocation à la méthacholine (qui cause une diminution de $20 \%$ du VEMS [méthacholine $\mathrm{PD}_{20}$ ]) et sur le monoxide d'azote expiré que l'emploi du CSI seul à faible dose. Cet effet n'était pas manifeste après l'administration d'une dose modérée de CSI.

\section{Comparaison entre les BALA et les ARLT en tant que traitement d'ajout aux CSI}

Deux études à forte participation ont porté sur la comparaison entre des ARLT et un BALA : la première portait sur l'emploi du zafirlukast (20 mg, 2 f.p.j.) et du salmétérol (50 $\mu$ g, 2 f.p.j.) chez 429 patients (69); l'autre portait sur celui du montélukast

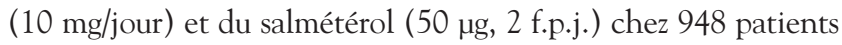
(70). Durant ces deux études, le salmétérol s'est révélé supérieur aux ARLT dans l'amélioration de la fonction respiratoire et de la qualité de la vie ainsi que dans la diminution des symptômes et du recours à un BACA de secours. Les différences observées pendant l'étude portant sur le montélukast étaient faibles et de portée clinique discutable (70). Aucune des études ne comportait de comparaison avec un placebo. Les résultats obtenus concordent avec ceux d'une autre étude (41) qui portait sur 447 adultes chez lesquels l'emploi de faibles doses de CSI ne permettait pas une maîtrise optimale. La prise biquotidienne de $100 \mu \mathrm{g}$ de fluticasone et de $50 \mu \mathrm{g}$ de salmétérol en association s'était révélée supérieure à l'emploi associé du montélukast (10 mg) et du fluticasone (100 g, 2 f.p.j.) dans l'amélioration de la fonction respiratoire, et la réduction des symptômes et de la fréquence d'exacerbation. Ringdal et ses collègues (71) ont comparé l'emploi associé du fluticasone $(100 \mu g, 2$ f.p.j. $)$ et du

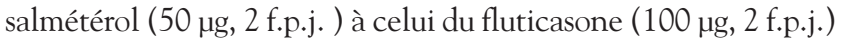
et du montélukast ( $10 \mathrm{mg} /$ jour $)$ chez 725 sujets atteints d'asthme modéré. Le DEP et le VEMS se sont améliorés davantage, et le nombre d'exacerbations a diminué davantage dans le groupe qui recevait le salmétérol que dans l'autre.

Une autre étude (72) comportait une comparaison entre l'ajout du montélukast (10 mg/jour) ou du salmétérol (50 $\mu$ g, 2 f.p.j.) à un CSI chez 20 patients pendant 2 semaines. On a observé dans les deux groupes une amélioration significative de la maîtrise de l'asthme, mais seul l'ajout du montélukast a eu un effet significatif sur les résultats de la provocation à l'adénosine-monophosphate et sur le taux sanguin des éosinophiles suggérant un effet antiinflamamtoire. Cependant, la dose et le type de CSI variaient entre sujets.

En conclusion, l'ajout d'un BALA à un CSI semble être plus efficace que l'ajout d'un ARLT à un CSI en ce qui a trait à la maîtrise de l'asthme quand la prise du CSI seul ne permet pas d'atteindre une maîtrise optimale de l'asthme. Il faudra mener d'autres études afin de confirmer la supériorité des ARLT sur les BALA en ce qui a trait à l'effet antiinflammatoire.

6. Conclusions et recommandations à propos de l'emploi
d'agents d'appoint dans le traitement de l'asthme
1. L'emploi d'un BALA en monothérapie n'est pas
recommandé dans le traitement d'entretien de
l'asthme ( Niveau I).
2. Si la prise de CSI à faible dose ne permet pas
d'obtenir une maîtrise adéquate de l'asthme après que
l'on ait réévalué l'observance au traitement, l'as-
sainissement de l'environnement et le diagnostic
d'asthme, le traitement devrait être modifié en y
ajoutant un BALA (Niveau I). L' ajout d'un ARLT
ou l'augmentation de la dose de CSI à une dose mod-
érée peuvent être également considérés.(Niveau I)
La théophylline peut constituer une troisième option
de traitement (Niveau II).

\section{Pistes de recherche}

1. Des études de longue durée sont nécessaires pour évaluer la maîtrise de l'asthme et le remodelage des voies aériennes après l'usage d'associations médicamenteuses pendant plusieurs années.

2. Il faudra mener d'autres études sur la possibilité de réduire la dose de CSI grâce à l'ajout d'ABAL ou d'ARLT à la corticothérapie. 
3. Des études sur le traitement de première intention de l'asthme comparant les traitements d'association à l'usage de doses modérées ou élevées de CSI seuls chez les patients n'ayant jamais reçu de CSI auparavant sont requises pour évaluer la supériorité éventuelle des associations médicamenteuses sur les CSI dans le traitement de première intention de l'asthme modéré.

4. Il faudra mener d'autres études afin de comparer la maîtrise de l'asthme et l'action anti inflammatoire des BALA et LTRA en tant que thérapie d'appoint.

\section{MISE À JOUR SUR L'ÉDUCATION DE L'ADULTE EN MATIÈRE D'ASTHME}

\section{Examen systématique}

Nous avons effectué une revue de littérature systématique concernant les études portant sur l'éducation dans l'asthme publiées en anglais après la dernière mise à jour des recommandations en 1999 (73). La recherche a été effectuée à partir de mots clés comme « asthma » et « education » dans la base de données MEDLINE (PubMed). Nous avons également examiné les recommandations publiées récemment $(9,10)$ et les analyses Cochrane pertinentes (74-76).

Les principaux aspects de l'éducation inclus dans cette revue sont le rôle de l'éducation dans la prise en charge de l'asthme, les effets de l'éducation sur la maîtrise de l'asthme, le suivi du patient et les plans d'action.

\section{Historique}

\subsection{Le fossé entre la prise en charge de l'asthme et l'équilibre de l'asthme}

Plusieurs enquêtes sur la prise en charge de l'asthme et sa maîtrise (77-79) menées au Canada ont indiqué que médecins et patients ne sont pas conscients du fossé qui sépare l'objectif de la prise en charge de l'asthme, soit la maîtrise de cette affection (3), et le degré de maîtrise véritablement atteint. Les mesures présentement prises au Canada comme dans d'autres pays ne permettent pas d'atteindre une maittrise satisfaisant de la maladie. Les lacunes en matière d'éducation des patients sont une des raisons de cet échec $(78,80)$. Néanmoins, on considère que la maîtrise de l'asthme est un objectif réaliste et souhaitable ; il constitue le principal objectif que devrait viser le traitement $(3,9,10)$.

La maitrise de l'asthme demeure insatisfaisante, même si un grand nombre de patients se voient prescrire des CSI (79). De nombreux patients ne comprennent pas bien le rôle de leurs médicaments et la manière de prendre ceux-ci $(78,81)$. Cette situation peut expliquer partiellement le faible degré d'observance du traitement d'entretien, notamment avec les CSI $(82,83)$. De plus, il se peut qu'un diagnostic clinique d'asthme n'ait pas été posé chez bien des personnes qui reçoivent des médicaments anti-asthmatiques ou qui consultent avec des symptômes similaires à ceux d'une crise d'asthme.

Il est également évident que les médecins n'évaluent pas nécessairement la maîtrise de l'asthme de manière uniforme ou systématique, et qu'ils n'expliquent pas clairement le but de la prise en charge de l'asthme ou la définition de la maîtrise de cette affection à leurs patients $(77,78)$. Si, et il semble bien que ce soit le cas, la médication adéquate est prescrite, seul un effort d'éducation visant à modifier les comportements des médecins et des patients permettra d'améliorer les résultats.

\subsection{L'éducation est elle efficace et quelle forme devrait elle prendre?}

Les résultats d'études clés et d'analyses effectuées dans le passé ont indiqué que l'asthme peut évoluer plus favorablement si le patient se prend bien en charge et reçoit une éducation de qualité $(84,85)$. Cependant, l'analyse comparée des programmes d'éducation en matière d'asthme est parfois difficile à cause de la diversité des méthodes pédagogiques appliquées, de la durée des programmes, des caractéristiques des participants et des moyens d'évaluation. Bien que ces programmes d'éducation ne comprennent pas toujours un moyen de mesurer leurs effets sur la maîtrise de l'asthme (3), il est logique que le programme offert vise à modifier les comportements des patients (ou des médecins) afin d'encourager l'observance des mesures de prise en charge. S'il est difficile d'améliorer la fidélité du patient au traitement prescrit (83), il en va de même pour toute mesure visant à modifier le comportement, peu importe la maladie chronique. Pour assurer le succès des programmes d'éducation en matière d'asthme, il faut adapter ces programmes aux besoins des patients, à leur capacité d'accepter le diagnostic et leur participation à la prise en charge de l'asthme (86). La difficulté de mesurer précisément les résultats de l'éducation, les résultats divergents des enquêtes portant sur les mêmes thèmes $(75,76)$ indique que les programmes d'éducation doivent être structurés avec soin, individualisés et appliqués avec expertise pour porter fruit.

\subsection{La connaissance de l'asthme et la modification des comportements}

La transmission de connaissances au patient n'implique pas une modification du comportement (87-89), même s'il s'agit probablement d'une première étape importante. Les éléments les plus efficaces de l'éducation en matière d'asthme comprennent l'apprentissage de l'emploi des dispositifs d'administration (p. ex., inhalateur), la compréhension des différences entre les médicaments qui soulagent et ceux qui contrôle les symptômes, et la recommandation de moyens de surveillance de la maladie et d'un plan d'action $(75,85)$. Les personnes chargées de l'éducation doivent avoir une connaissance approfondie de l'asthme, la formation nécessaire et une aptitude éprouvée à stimuler des changements comportementaux (90). Il est probable que l'éducation offerte par les médecins est la plupart du temps très limitée et loin du modèle idéal $(91,92)$. Néanmoins, il est essentiel que les médecins participent à l'éducation de leurs patients et qu'ils appuient le rôle des éducateurs.

\subsection{Qui faut il éduquer?}

En général, l'impact de l'éducation devrait être plus important chez les patients les plus sévères, notamment ceux qu'on retrouve dans les salles d'urgence et ceux qu'il faut hospitaliser (93-95). Il se peut également que ces patients soient plus réceptifs aux interventions éducatives (93-95). À ce propos, Côté et ses collègues (94) ont fait état d'un groupe de patients 
recrutés alors qu'ils s'étaient rendus au service des urgences à cause d'une exacerbation de leur asthme. Trois groupes de patients avaient été enrôlés : ceux qui recevaient les soins habituels, ceux qui recevaient une brève séance d'éducation au service des urgences et ceux qui recevaient cette même séance d'éducation et qui étaient orientés vers un éducateur spécialisé dans le domaine de l'asthme. Les paramètres relatifs à l'asthme se sont améliorés significativement uniquement dans le dernier groupe, notamment la fréquence de consultation aux urgences qui a diminué par la suite.

\section{3. Évaluations récentes des programmes d'éducation en matière d'asthme}

Dernièrement, les résultats d'autres études sont venus appuyer l'importance et la pertinence de l'éducation quant à la participation du patient à la prise en charge globale de l'asthme. Notre examen s'est toutefois limité aux études portant sur des adultes.

Pendant trois ans, Yilmaz et Akkaya (96) ont étudié un mode d'intervention éducative s'appuyant sur des vidéocassettes visionnées en consultation externe, des brochures pour le patient, la vérification de la bonne technique d'inhalation, l'éducation du patient, des séminaires d'éducation en 6 volets animés par un pneumologue et l'accès à une ligne d'aide par téléphone. Suivant une répartition aléatoire, 52 patients asthmatiques présentant au départ une obstruction aérienne notable ont fait l'objet d'une intervention éducative $(\mathrm{n}=25)$ ou ont reçu les soins habituels $(n=27)$. Au bout de trois ans, on a observé une amélioration significative des scores relatifs à la connaissance de l'asthme, de la qualité de la vie et de la sévérité de l'asthme ainsi qu'une réduction de la fréquence des visites aux urgences dans le groupe qui avait fait l'objet de l'intervention éducative. La fréquence d'hospitalisation est toutefois restée comparable dans les deux groupes. Les scores relatifs aux symptômes diurnes et nocturnes d'asthme ont également tendu à s'améliorer dans le groupe éduqué.

Couturaud et ses collègues (97) ont fait état d'une étude comparative d'un an avec répartition aléatoire portant sur 72 patients. La moitié des participants a reçu les soins habituels (groupe témoin) et l'autre moitié (groupe éduqué) a participé à 5 séances individuelles portant sur la physiopathologic de l'asthme, le rôle de la pharmacothérapie et ses effets indésirables, les déclencheurs de l'asthme et les moyens de les éviter, la reconnaissance des exacerbations d'asthme et le plan de prise en charge personnelle fondé sur la surveillance des symptômes et des débits de pointe. Les jours sans symptômes ont été plus nombreux chez les membres du groupe traité qui ont suivi le plan d'action que dans le groupe témoin, tandis qu'à la fin de l'étude, le nombre de jours sans symptômes était dans l'ensemble comparable dans les deux groupes. Les changements observés se comparaient dans les deux groupes, de même que les cotes de qualité de la vie. On n’a décelé aucune différence entre les groupes quant à la connaissance de l'asthme. Cependant, les scores relatifs à l'aptitude à se prendre en charge étaient significativement plus élevés dans le groupe éduqué au bout d' un an.

Dans le cadre d'un essai comparatif de 12 mois avec répartition aléatoire portant sur des adultes, Osman et ses collègues (98) ont examiné l'influence d'un court programme de prise en charge personnelle sur la fréquence subséquente d'hospitalisation pour cause d'asthme. L'intervention comportait une heure de formation appuyant un plan écrit de prise en charge personnelle et remise pendant l'hospitalisation pour une crise d'asthme aiguë. Le groupe témoin recevait les soins standard. Un mois après l'obtention du congé, la probabilité que le patient ne rapporte aucun symptôme diurne ou nocturne et aucune restriction dans ses activités était plus élevée dans le groupe éduqué que le groupe témoin. Au cours du suivi de un an, 17 \% des patients éduqué et $27 \%$ des sujets témoins ont été hospitalisés de nouveau. Cette différence en faveur du programme d'éducation était significative pour ceux dont c'était la première hospitalisation au moment de leur admission à l'étude, tandis que la réduction de fréquence d'hospitalisation tendait à être significative chez ceux qui avaient déjà été hospitalisés auparavant. À la sortie de l'hôpital, il était plus probable que l'on prescrive des CSI et des corticostéroïdes oraux aux membres du groupe éduqué, et que l'on assure le suivi de leur état; cependant, après ajustement pour ces différences, les bienfaits observés étaient toujours significativement plus grands chez les éduqués dont c'était la première hospitalisation pour cause d'asthme au moment du recrutement que chez leurs homologues du groupe témoin. Les résultats de cette étude témoignent de l'influence d'une telle intervention de première intention chez le patient atteint d'asthme aigu, surtout pour celui qui est hospitalisé pour la première fois pour cause d'asthme. Ils incitent également à penser que le programme d'éducation orientait l'exercice de la médecine vers une plus grande observance des recommandations actuelles sur l'asthme. Les auteurs avancent que ce résultat pourrait découler de la communication entre l'éducateur et le médecin. Ils proposent également qu'il faut profiter de l'hospitalisation du patient pour lui montrer comment améliorer la maîtrise de son asthme.

Put et ses collègues (99) ont évalué une intervention chez des patients atteints d'asthme léger ou modéré qui furent randomisés à un programme d'éducation ou reçurent les soins habituels. Le programme comprenait un cahier contenant des renseignements, des exercices et des devoirs. Des techniques psychopédagogiques et cognitivo-comportementales ont également été présentées au cours de 6 séances individuelles de 1 heure. On a rapporté moins de symptômes, une meilleure qualité de la vie, une plus grande diminution des sentiments négatifs, une plus grande fidélité au traitement et une plus grande amélioration de diverses variables cognitives dans le groupe éduqué que le groupe témoin. Les auteurs ont conclu que la participation à un programme individualisé se traduisait par une réduction de la morbidité liée à l'asthme ainsi qu'une amélioration des comportements liés à l'asthme et des connaissances chez les sujets symptomatiques et limités dans leur performances malgré un traitement médical adéquat. La validité des résultats est toutefois limitée parce que la période d'observation n'était que de 3 mois; idéalement, l'évaluation devrait durer plus longtemps.

Thoonen et ses collègues (100) ont comparé un programme de prise en charge personnelle aux soins habituels chez des patients traités dans un cadre de médecine générale. L'intervention a pris la forme de 4 séances de formation de 30, 20, 10 et 10 minutes respectivement. Au cours du suivi de deux ans, la maîtrise de l'asthme s'est révélée significativement 
meilleure et les jours où les activités sont limitées par l'asthme étaient moins nombreux chez ceux qui avaient fait l'objet de cette intervention (groupe éduqué). Dans le groupe éduqué, les scores relatifs à la qualité de la vie s'étaient améliorés, de manière significative dans le domaine des émotions. Fait à remarquer, on a également observé une réduction globale des doses de CSI administrées mais une hausse du nombre de cures de corticostéroïdes oraux dans le groupe de 110 patients éduqués. La fréquence d'exacerbation et les résultats des évaluations spirométriques se comparaient dans les deux groupes. En revanche, Ignacio Garcia et ses collègues (101) ont démontré une baisse de la fréquence d'exacerbation et du recours aux corticostéroïdes oraux ainsi qu'une amélioration de la fonction respiratoire chez les patients éduqués pendant une étude des effets d'un programme de prise en charge personnelle. Ces bienfaits manifestes au bout de 3 ans ont été attribués aux séances de renforcement effectuées 3, 6, 12, 24 et 36 mois après l'admission à l'étude.

\section{Assainissement de l'environnement}

Une sous-analyse d'un essai mené précédemment par Côté et ses collègues (102) a permis de mettre en évidence une amélioration des mesures visant l'environnement et de la qualité de la vie après la mise en œuvre d'un programme éducatif structuré. Cependant, ces mesures ont surtout été efficaces en ce qui à l'élimination des acariens; celles qui visaient à limiter l'exposition à un animal de compagnie ont eu moins de succès. Il faudrait mener d'autres études à ce sujet, car il semble très difficile de modifier le comportement des patients face à leur animal de compagnie.

\section{5. Éducation de l'adolescent}

Cowie et ses collègues (103) ont fait état de 93 patients ayant entre 15 et 20 ans qui s'étaient rendus aux urgences à cause de leur asthme. Suivant une répartition aléatoire, ces patients ont participé à un programme d'évaluation, d'éducation et de prise en charge adapté à leur âge et administré par des éducateurs, des inhalothérapeutes et des médecins, ou ont reçu les soins habituels de leur médecin traitant. Au bout de 6 mois, 62 des patients ont rempli un questionnaire. On a relevé une amélioration marquée de la maîtrise de l'asthme chez les participants des deux groupes ainsi qu'une réduction de $73 \%$ de la fréquence des visites aux urgences, et une amélioration de la qualité de la vie liée à la maladie. Il n'existait aucune différence entre les deux groupes, mais les participants au programme d'éducation ont répondu plus favorablement aux questions sur la qualité de la vie portant sur les symptômes et les facteurs affectifs. On peut donc arriver à une amélioration significative chez l'adolescent, même si la prise en charge de l'asthme semble plus difficile chez ce type de patient. Cependant, il est étonnant que les résultats ne soient pas significativement meilleurs dans le groupe traité que le groupe témoin. Il se peut que les membres des deux groupes qui ont participé à l'étude jusqu'à la fin aient été les plus observants et que les membres du groupe témoin aient été influencés par leurs pairs éduqués. Comme ces patients ont été admis alors que leur état était instable, une régression vers la moyenne pourrait expliquer les changements observés, et il aurait été intéressant de mener un suivi plus long. En effet, dans le cadre de l'étude menée par Côté et ses collègues (94), la diminution des consultations aux urgences n'était devenue apparente dans le groupe éduqué qu'après les six premiers mois du suivi.

Au cours d'une autre étude portant sur des adolescents, l'éducation était assurée par les pairs (104). Les modifications de la qualité de la vie évaluées au moyen de l'outil Juniper étaient manifestes dans certains domaines, de même que chez certains des groupes d'enfants exposés à l'intervention éducative et non dans les groupes témoins. La qualité de la vie s'était améliorée globalement chez les enfants éduqués, mais la différence n'était significative que dans le domaine des activités et surtout chez les filles, tandis que dans le domaine affectif, on a relevé une amélioration significative chez les garçons, mais pas de différence globale.

\section{Formation des professionnels de la santé et des éducateurs}

Malheureusement, il existe peu d'études du rendement et de l'efficacité des programmes de formation à l'intention des éducateurs, et en autant que nous sachions, aucune n'a été menée depuis 1999. Au Canada, les éducateurs certifiés en matière d'asthme suivent un programme de formation donnant droit à des crédits et passent un examen reconnu à l'échelle nationale. Tout patient atteint asthme modéré ou grave, surtout s'il a de graves épisodes exacerbés, doit être orienté vers un programme d'éducation administré par un éducateur qualifié. La liste des programmes offerts figure sur le site web du RCTA à l'adresse < http://www.cnac.net/english/clinics.html> et sur le site du Réseau québécois de l'asthme et de la M.P.O.C. à l'adresse < http://www.rqam.ca $>$.

\section{Répercussions sur la recherche}

Il faut poursuivre l'étude de l'optimisation de l'éducation en matière d'asthme, surtout chez des patients ciblés comme ceux qui sont gravement atteints, les adolescents et les personnes âgées. L'éducation est un important élément des recommandations sur le traitement de l'asthme, et son intégration aux soins actuellement offerts doit être encouragée par les plans d'application des recommandations (105). On a conçu divers programmes éducatifs, et il faut établir plus précisément les éléments primordiaux qui favorisent la modification des comportements. Il semble essentiel d'élaborer un plan d'action et de revoir le patient périodiquement, mais la façon d'optimiser l'efficacité et la rentabilité de tels programmes reste à valider dans certaines populations. La mise en pratique de ces interventions doit tenir compte des ressources disponibles ainsi que des différences socioéconomiques et culturelles.

D'après les résultats d'études antérieures, les effets de tels programmes varient selon la population ciblée. Par exemple, ces effets sont plus prononcés quand la morbidité liée à l'asthme est importante et dépendent probablement du type d'intervention, de la formation des éducateurs, de l'articulation des diverses mesures d'intervention, des méthodes analytiques et de la durée de l'étude. Ces facteurs doivent être pris en considération dans la conception des études portant sur l'efficacité des programmes éducatifs et mentionnés dans les rapports d'études. L'effet confondant du traitement simultané par les glucocorticoïdes doit être pris en compte, et les résultats 
ajustés en conséquence, même s'il n'est pas toujours facile de distinguer les effets de la pharmacothérapie de ceux de l'intervention éducative.

\section{Recommandations sur l'éducation et la surveillance de l'asthme}

1. L'éducation fait partie intégrante du traitement de l'asthme et doit être accessible à tous les patients. Une intervention éducative peut être particulièrement bénéfique lorsqu'initiée pendant les visites à l'urgence ou les hospitalisations. (Niveau I).

2. Tous les patients devraient disposer d'un plan d'action écrit qui comporte l'ajustement de la médication en fonction de la sévérité ou de la fréquence des symptômes ainsi que la médication nécessaire à leur soulagement (Niveau I).

3. L'auto-surveillance pratiquée par le patient en utilisant soit la mesure du débit expiratoire de pointe (DEP) soit la surveillance des symptômes d'asthme est efficace (Niveau I).

4. La mesure du débit expiratoire devrait être effectuée régulièrement de préférence par spirométrie (Niveau III).

5. La mesure sériée des DEP pourrait s'avérer utile chez certains patients, notamment chez ceux qui perçoivent mal l'obstruction des voies respiratoires (Niveau III).

6. La prise en charge optimale de l'asthme devrait inclure des suivis médicaux et éducatifs réguliers (Niveau I).

7. Les critères de maîtrise de l'asthme devraient être reévalués à chaque visite (Niveau IV).

8. Des facteurs socio-économiques et culturels devraient entrer en ligne de compte lors de la formulation des programmes éducatifs (Niveau II).

9. Les programmes éducatifs devraient inclure un processus d'évaluation du rendement du programme par rapport aux objectifs établis (Niveau III).

\section{Pistes de recherche}

1. Quel est l'effet de l'accréditation des éducateurs sur le processus d'éducation en matière d'asthme et les résultats cliniques?

2. Quels sont les éléments essentiels du programme d'éducation en matière d'asthme?

3. Comment reconnaît on le patient à un risque élevé chez qui l'éducation pourrait être particulièrement utile?

4. Quel est le meilleur moyen d'évaluer l'observance du traitement contre l'asthme?

5. Comment intégrer efficacement l'éducation en matière d'asthme à l'exercice de la médecine?

ORGANISME COMMANDITAIRE : Société de thoracologie du Canada

REMERCIEMENTS : Nous remercions les Drs Louis-Philippe Boulet, Meyer Balter, Allan Becker, Dennis Bowie, Robert Cowie, Donald Cockcroft, Ken Chapman, Francine M. Ducharme, Mark Fitzgerald, Donna Hogg, Catherine Lemière et Paul O'Byrne pour leur précieuse collaboration à la rédaction de ce document. Nos remerciements s'adressent également à Mme Valoree McKay pour son soutien administratif remarquable.

INTÉRÊTS OPPOSÉS : Les médecins siégeant au comité d'examen scientifique ont tous agi au moins une fois à titre de consultants pour ALTANA Pharma Inc., AstraZeneca Canada, GlaxoSmithKline Inc., Merck Frosst Inc. et Produits pharmaceutiques $3 \mathrm{M}$, ou reçu des subventions de recherche ou de déplacement, ou des honoraires de conférencier de ces sociétés.

SOUTIEN FINANCIER : Ces recommandations ont été formulées sous les auspices de la Société de thoracologie du Canada. Ce processus a été facilité par des contributions inconditionnelles à visée éducative d'ALTANA Pharma Inc., d'AstraZeneca Canada, de GlaxoSmithKline Inc., de Merck Frosst Inc. et de Produits pharmaceutiques $3 \mathrm{M}$. 


\section{REFERENCES}

1. Hargreave F, Dolovich J, Newhouse M. The assessment and treatment of asthma: A conference report. J Allergy Clin Immunol 1990;85:1098-111.

2. Ernst P, Fitzgerald J, Spier S. Conférence canadienne de consensus sur l'asthme. Résumé des recommandations / Canadian Asthma Consensus Conference. Summary of Recommendations. Can Respir J 1996;3:89-114.

3. Boulet LP, Becker A, Berube D, Beveridge R, Ernst P. Canadian Asthma Consensus Report, 1999. Canadian Asthma Consensus Group. CMAJ 1999;161(11 Suppl):S1-61.

4. Boulet LP, Bai T, Becker A, et al. What is new since the last (1999) Canadian Asthma Consensus Guidelines? Can Respir J 2001;8(Suppl A):5A-27A.

5. Steering Committee on Clinical Practice Guidelines for the Care and Treatment of Breast Cancer. A Canadian consensus document. CMAJ 1998;158(3 Suppl):S2.

6. D'Amato G, Oldani V, Donner CF. Anti-IgE monoclonal antibody: A new approach to the treatment of allergic respiratory diseases. Monaldi Arch Chest Dis 2003;59:25-9.

7. Green RH, Brightling CE, McKenna S, et al. Asthma exacerbations and sputum eosinophil counts: A randomised controlled trial. Lancet 2002;360:1715-21.

8. Bates CA, Silkoff PE. Exhaled nitric oxide in asthma: From bench to bedside. J Allergy Clin Immunol 2003;111:256-62.

9. NHLBI/WHO Workshop Report. Global Strategy for Asthma Management and Prevention.

$<$ http://www.ginasthma.com/wr_clean.pdf $>$ (Version current at February 13, 2004).

10. British Thoracic Society, Scottish Intercollegiate Guidelines Network. British guideline on the management of asthma. Thorax 2003;58(Suppl 1):i1-94

11. Pauwels R, Löfdahl C, Postma D, et al. Effect of inhaled formoterol and budesonide on exacerbations of asthma. N Engl J Med 1997;337:1405-11.

12. Greening A, Ind P, Northfield M, Shaw G. Added salmeterol versus higher-dose corticosteroid in asthma patients with symptoms on existing inhaled corticosteroid. Lancet 1994;344:219-24.

13. Adams NP, Bestall JB, Jones PW. Inhaled beclomethasone versus placebo for chronic asthma (Cochrane Review). The Cochrane Library, issue 1. Oxford: Update Software, 2003.

14. Hatoum HT, Schumock GT, Kendzierski DL. Meta-analysis of controlled trials of drug therapy in mild chronic asthma: The role of inhaled corticosteroids. Ann Pharmacother 1994;28:1285-9.

15. Adams NP, Bestall JB, Jones PW. Fluticasone versus beclomethasone or budesonide for chronic asthma (Cochrane Review). The Cochrane Library, issue 1. Oxford: Update Software, 2003.

16. Adams NP, Bestall JB, Jones PW. Inhaled budesonide at different doses for chronic asthma (Cochrane Review). The Cochrane Library, issue 1. Oxford: Update Software, 2003.

17. Pauwels RA, Pedersen S, Busse WW, et al. Early intervention with budesonide in mild persistent asthma: A randomised, double-blind trial. Lancet 2003;361:1071-6.

18. Shrewsbury S, Pyke S, Britton M. Meta-analysis of increased dose of inhaled steroid or addition of salmeterol in symptomatic asthma (MIASMA). BMJ 2000;320:1368-73.

19. O'Byrne PM, Barnes PJ, Rodriguez-Roisin R, et al. Low dose inhaled budesonide and formoterol in mild persistent asthma: The OPTIMA randomized trial. Am J Respir Crit Care Med 2001;164:1392-7.

20. Baumgarten C, Geldszus R, Behre U, Peslis N, Trautmann M, Viani-Initial Study Group. Initial treatment of symptomatic mild to moderate bronchial asthma with the salmeterol/fluticasone propionate (50/250 microg) combination product (SAS 40023). Eur J Med Res 2002;7:1-7.

21. Ducharme FM. Inhaled glucocorticoids versus leukotriene receptor antagonists as single agent asthma treatment: Systematic review of current evidence. BMJ 2003;326:621.

22. Aubier M, Pieters WR, Schlosser NJ, Steinmetz KO. Salmeterol/fluticasone propionate $(50 / 500 \mathrm{microg})$ in combination in a Diskus inhaler (Seretide) is effective and safe in the treatment of steroid-dependent asthma. Respir Med 1999;93:876-84.

23. Bleecker ER, Welch MJ, Weinstein SF, et al. Low-dose inhaled fluticasone propionate versus oral zafirlukast in the treatment of persistent asthma. J Allergy Clin Immunol 2000;105:1123-9.
24. Busse W, Raphael GD, Galant S, et al. Low-dose fluticasone propionate compared with montelukast for first-line treatment of persistent asthma: A randomized clinical trial. J Allergy Clin Immunol 2001;107:461-8

25. Busse W, Wolfe J, Storms W, et al. Fluticasone propionate compared with zafirlukast in controlling persistent asthma: A randomized double-blind, placebo-controlled trial. J Fam Pract 2001:50:595-602.

26. Busse W, Koenig SM, Oppenheimer J, et al. Steroid-sparing effects of fluticasone propionate 100 microg and salmeterol 50 microg administered twice daily in a single product in patients previously controlled with fluticasone propionate 250 microg administered twice daily. J Allergy Clin Immunol 2003;111:57-65.

27. Calhoun WJ, Nelson HS, Nathan RA, et al. Comparison of fluticasone propionate-salmeterol combination therapy and montelukast in patients who are symptomatic on short-acting beta(2)-agonists alone. Am J Respir Crit Care Med 2001;164:759-63.

28. Chalmers GW, Macleod KJ, Little SA, Thomson LJ, McSharry CP, Thomson NC. Influence of cigarette smoking on inhaled corticosteroid treatment in mild asthma. Thorax 2002;57:226-30.

29. Condemi JJ, Goldstein S, Kalberg C, Yancey S, Emmett A, Rickard $\mathrm{K}$. The addition of salmeterol to fluticasone propionate versus increasing the dose of fluticasone propionate in patients with persistent asthma. Salmeterol Study Group. Ann Allergy Asthma Immunol 1999;82:383-9.

30. Dempsey OJ, Fowler SJ, Wilson A, Kennedy G, Lipworth BJ. Effects of adding either a leukotriene receptor antagonist or low-dose theophylline to a low or medium dose of inhaled corticosteroid in patients with persistent asthma. Chest 2002;122:151-9.

31. Fairfax A, Hall I, Spelman R. A randomized, double-blind comparison of beclomethasone dipropionate extrafine aerosol and fluticasone propionate. Ann Allergy Asthma Immunol 2001;86:575-82.

32. Fernandes AL, Faresin SM, Amorim MM, Fritscher CC, Pereira CA, Jardim JR. Inhaled budesonide for adults with mild-to-moderate asthma: A randomized placebo-controlled, double-blind clinical trial. Sao Paulo Med J 2001;119:169-74.

33. Fireman P, Prenner BM, Vincken W, Demedts M, Mol SJ, Cohen RM. Long-term safety and efficacy of a chlorofluorocarbonfree beclomethasone dipropionate extrafine aerosol. Ann Allergy Asthma Immunol 2001;86:557-65.

34. Frew AJ, Langley SJ, Perrin V, Hertog MG. Effects of 4-week treatment with low-dose budesonide (100 micrograms BID) from a novel inhaler Airmax and from a conventional inhaler on bronchial hyper-responsiveness, lung function and symptoms in patients with mild asthma. Respir Med 2002;96:542-7.

35. Goldin JG, Tashkin DP, Kleerup EC, et al. Comparative effects of hydrofluoroalkane and chlorofluorocarbon beclomethasone dipropionate inhalation on small airways: Assessment with functional helical thin-section computed tomography. J Allergy Clin Immunol 1999;104:S258-67.

36. Juniper EF, Price DB, Stampone PA, Creemers JP, Mol SJ, Fireman P. Clinically important improvements in asthma-specific quality of life, but no difference in conventional clinical indexes in patients changed from conventional beclomethasone dipropionate to approximately half the dose of extrafine beclomethasone dipropionate. Chest 2002;121:1824-32.

37. Kavuru M, Melamed J, Gross G, et al. Salmeterol and fluticasone propionate combined in a new powder inhalation device for the treatment of asthma: A randomized, double-blind, placebo-controlled trial. J Allergy Clin Immunol 2000;105:1108-16.

38. Kim KT, Ginchansky EJ, Friedman BF, et al. Fluticasone propionate versus zafirlukast: Effect in patients previously receiving inhaled corticosteroid therapy. Ann Allergy Asthma Immunol 2000;85:398-406.

39. Matz J, Emmett A, Rickard K, Kalberg C. Addition of salmeterol to low-dose fluticasone versus higher-dose fluticasone: An analysis of asthma exacerbations. J Allergy Clin Immunol 2001;107:783-9.

40. Meltzer EO, Lockey RF, Friedman BF, et al. Efficacy and safety of low-dose fluticasone propionate compared with montelukast for maintenance treatment of persistent asthma. Mayo Clin Proc 2002;77:437-45. 
41. Nelson HS, Busse WW, Kerwin E, et al. Fluticasone propionate/salmeterol combination provides more effective asthma control than low-dose inhaled corticosteroid plus montelukast. J Allergy Clin Immunol 2000;106:1088-95.

42. Van Noord JA, Schreurs AJ, Mol SJ, Mulder PG. Addition of salmeterol versus doubling the dose of fluticasone propionate in patients with mild to moderate asthma. Thorax 1999;54:207-12.

43. Price D, Dutchman D, Mawson A, Bodalia B, Duggan S, Todd P. Early asthma control and maintenance with eformoterol following reduction of inhaled corticosteroid dose. Thorax 2002;57:791-8.

44. Pearlman DS, White MV, Lieberman AK, et al. Fluticasone propionate/salmeterol combination compared with montelukast for the treatment of persistent asthma. Ann Allergy Asthma Immunol 2002;88:227-35.

45. Tukiainen H, Taivainen A, Majander R, et al. Comparison of high and low dose of the inhaled steroid, budesonide, as an initial treatment in newly detected asthma. Respir Med 2000;94:678-83.

46. Vagaggini B, Taccola M, Conti I, et al. Budesonide reduces neutrophilic but not functional airway response to ozone in mild asthmatics. Am J Respir Crit Care Med 2001;164:2172-6.

47. Volovitz B, Nussinovitch M, Finkelstein Y, Harel L, Varsano I. Effectiveness of inhaled corticosteroids in controlling acute asthma exacerbations in children at home. Clin Pediatr (Phila) 2001:40:79-86

48. Lofdahl CG, Reiss TF, Leff JA, et al. Randomised, placebo controlled trial of effect of a leukotriene receptor antagonist, montelukast, on tapering inhaled corticosteroids in asthmatic patients. BMJ 1999;319:87-90.

49. Evans DJ, Taylor DA, Zetterstrom O, Chung KF, O'Connor BJ, Barnes PJ. A comparison of low-dose inhaled budesonide plus theophylline and high-dose inhaled budesonide for moderate asthma. N Engl J Med 1997;337:1412-8.

50. Lazarus SC, Boushey HA, Fahy JV, et al. Long-acting beta 2 -agonist monotherapy vs continued therapy with inhaled corticosteroids in patients with persistent asthma: A randomized controlled trial. JAMA 2001;285:2583-93.

51. Lemanske RF Jr, Sorkness CA, Mauger EA, et al. Inhaled corticosteroid reduction and elimination in patients with persistent asthma receiving salmeterol: A randomized controlled trial. JAMA 2001:285:2594-603.

52. Wooltorton E. Salmeterol (Serevent) asthma trial halted early. CMAJ 2003;168:738.

53. Woolcock A, Lundback B, Ringdal N, Jacques L. Comparison of addition of salmeterol to inhaled steroids with doubling of the dose of inhaled steroids. Am J Respir Crit Care Med 1996;153:1481-8.

54. Zetterstrom $\mathrm{O}$, Buhl R, Mellem H, et al. Improved asthma control with budesonide/formoterol in a single inhaler, compared with budesonide alone. Eur Respir J 2001;18:262-8.

55. D’Urzo AD, Chapman KR, Cartier A, Hargreave FE, Fitzgerald M, Tesarowski D. Effectiveness and safety of salmeterol in nonspecialist practice settings. Chest 2001;119:714-9.

56. Heyneman CA, Crafts R, Holland J, Arnold AD. Fluticasone versus salmeterol/low-dose fluticasone for long-term asthma control. Ann Pharmacother 2002;36:1944-9.

57. Fowler SJ, Lipworth BJ. Salmeterol and inhaled corticosteroids in patients with persistent asthma. JAMA 2001;286:3076-7.

58. Ducharme FM. Anti-leukotrienes as add-on therapy to inhaled glucocorticoids in patients with asthma: Systematic review of current evidence. BMJ 2002;324:1545.

59. Robinson DS, Campbell D, Barnes PJ. Addition of leukotriene antagonists to therapy in chronic persistent asthma: A randomised double-blind placebo-controlled trial. Lancet 2001;357:2007-11.

60. Lipworth BJ, Fowler S, Currie G. Montelukast for persistent asthma. Lancet 2001;358:1455.

61. Morice AH. Montelukast for persistent asthma. Lancet 2001;358:1455-6.

62. Cockcroft DW. Principles of asthma management in adults. In: Fitzgerald M, Ernst P, Boulet LP, O’Byrne PM, eds. Evidence Based Asthma. Hamilton: BC Decker Inc, 2001:111-20.

63. O'Sullivan S, Akveld M, Burke CM, Poulter LW. Effect of the addition of montelukast to inhaled fluticasone propionate on airway inflammation. Am J Respir Crit Care Med 2003;167:745-50.

64. Vaquerizo MJ, Casan P, Castillo J, et al. Effect of montelukast added to inhaled budesonide on control of mild to moderate asthma. Thorax 2003;58:204-10.
65. Price DB, Hernandez D, Magyar P, et al. Randomised controlled trial of montelukast plus inhaled budesonide versus double dose inhaled budesonide in adult patients with asthma. Thorax 2003;58:211-6.

66. Kanniess F, Richter K, Janicki S, Schleiss MB, Jorres RA, Magnussen H. Dose reduction of inhaled corticosteroids under concomitant medication with montelukast in patients with asthma. Eur Respir J 2002;20:1080-7.

67. Tohda Y, Fujimura M, Taniguchi $\mathrm{H}$, et al. Leukotriene receptor antagonist, montelukast, can reduce the need for inhaled steroid while maintaining the clinical stability of asthmatic patients. Clin Exp Allergy 2002;32:1180-6.

68. Yurdakul AS, Calisir HC, Tunctan B, Ogretensoy M. Comparison of second controller medications in addition to inhaled corticosteroid in patients with moderate asthma. Respir Med 2002;96:322-9.

69. Nelson HS, Nathan RA, Kalberg C, Yancey SW, Rickard KA. Comparison of inhaled salmeterol and oral zafirlukast in asthmatic patients using concomitant inhaled corticosteroids. MedGenMed 2001;3:3.

70. Fish JE, Israel E, Murray JJ, et al. Salmeterol powder provides significantly better benefit than montelukast in asthmatic patients receiving concomitant inhaled corticosteroid therapy. Chest 2001;120:423-30

71. Ringdal N, Eliraz A, Pruzinec R, et al. The salmeterol/fluticasone combination is more effective than fluticasone plus oral montelukast in asthma. Respir Med 2003;97:234-41.

72. Wilson AM, Dempsey OJ, Sims EJ, Lipworth BJ. Evaluation of salmeterol or montelukast as second-line therapy for asthma not controlled with inhaled corticosteroids. Chest 2001;119:1021-6.

73. Côté J, Kovesi T. Patient education. Can Respir J 2001;8(Suppl A):12A-5A

74. Powell H, Gibson PG. Options for self management education for adults with asthma (Cochrane Review). The Cochrane Library, issue 3. Oxford: Update Software, 2003.

75. Gibson PG, Powell H, Coughlan J. Self-management education and regular practitioner review for adults with asthma (Cochrane Review). The Cochrane Library, issue 3. Oxford: Update Software, 2003.

76. Toelle BG, Ram FS. Written individualised management plans for asthma in children and adults (Cochrane Review). The Cochrane Library, issue 3. Oxford: Update Software, 2003.

77. Boulet LP, Phillips R, O'Byrne P, Becker A. Evaluation of asthma control by physicians and patients: Comparison with current guidelines. Can Respir J 2002;9:417-23.

78. Chapman KR, Ernst P, Grenville A, Dewland P, Zimmerman S. Control of asthma in Canada: Failure to achieve guideline targets. Can Respir J 2001;8(Suppl A):35A-40A.

79. Cowie RL, Underwood MF, Mack S. The impact of asthma management guideline dissemination on the control of asthma in the community. Can Respir J 2001;8(Suppl A):41A-5A.

80. Bateman ED, Bousquet J, Braunstein GL. Is overall asthma control being achieved? A hypothesis-generating study. Eur Respir J 2001;17:589-95.

81. Boulet LP. Perception of the role and potential side effects of inhaled corticosteroids among asthmatic patients. Chest 1998;113:587-92.

82. Cochrane MG, Bala MV, Downs KE, Mauskopf J, Ben Joseph RH. Inhaled corticosteroids for asthma therapy: Patient compliance, devices, and inhalation technique. Chest 2000;117:542-50.

83. Haynes RB. Interventions for helping patients to follow prescriptions for medications (Cochrane Review). The Cochrane Library, issue 3. Oxford: Update Software, 2003.

84. Huzel L, Roos LL, Anthonisen NR, Manfreda J. Diagnosing asthma: The fit between survey and administrative database. Can Respir J 2002:9:407-12

85. Boulet LP. Asthma education: What has been its impact? Can Respir J 1998;5(Suppl A):91A-6A.

86. Green LW, Frankish CJ. Theories and principles of health education applied to asthma. Chest 1994;106(4 Suppl):219S-30S.

87. Kolbe J, Vamos M, James F, Elkind G, Garrett J. Assessment of practical knowledge of self-management of acute asthma. Chest 1996;109:86-90.

88. Gibson PG, Coughlan J, Wilson AJ. Limited (information only) patient education programs for adults with asthma (Cochrane Review). The Cochrane Library, issue 2. Oxford: Update Software, 2001 
89. Morice AH, Wrench C. The role of the asthma nurse in treatment compliance and self-management following hospital admission. Respir Med 2001;95:851-6.

90. Clark NM, Partridge MR. Strengthening asthma education to enhance disease control. Chest 2002;121:1661-9.

91. Cicutto LC, Llewellyn-Thomas HA, Geerts WH. Physicians' approaches to providing asthma education to patients and the level of patient involvement in management decisions. J Asthma 1999;36:427-39.

92. Jin R, Choi BC, Chan BT, et al. Physician asthma management practices in Canada. Can Respir J 2000;7:456-65.

93. FitzGerald JM, Turner MO. Delivering asthma education to special high risk groups. Patient Educ Couns 1997;32(Suppl 1):S77-86.

94. Côté J, Bowie DM, Robichaud P, Parent JG, Battisti L, Boulet LP. Evaluation of two different educational interventions for adult patients consulting with an acute asthma exacerbation. Am J Respir Crit Care Med 2001;163:1415-9.

95. Cowie RL, Revitt SG, Underwood MF, Field SK. The effect of a peak flow-based action plan in the prevention of exacerbations of asthma. Chest 1997;112:1534-8.

96. Yilmaz A, Akkaya E. Evaluation of long-term efficacy of an asthma education programme in an out-patient clinic. Respir Med 2002;96:519-24

97. Couturaud F, Proust A, Frachon I, et al. Education and self-management: A one-year randomized trial in stable adult asthmatic patients. J Asthma 2002;39:493-500.
98. Osman LM, Calder C, Godden DJ, et al. A randomised trial of self-management planning for adult patients admitted to hospital with acute asthma. Thorax 2002;57:869-74.

99. Put C, van den Bergh O, Lemaigre V, Demedts M, Verleden G. Evaluation of an individualised asthma programme directed at behavioural change. Eur Respir J 2003;21:109-15.

100. Thoonen BP, Schermer TR, Van Den BG, et al. Self-management of asthma in general practice, asthma control and quality of life: A randomised controlled trial. Thorax 2003;58:30-6.

101. Ignacio-Garcia JM, Pinto-Tenorio M, Chocron-Giraldez MJ, et al. Benefits at 3 yrs of an asthma education programme coupled with regular reinforcement. Eur Respir J 2002;20:1095-101.

102. Côté J, Cartier A, Robichaud P, et al. Influence of asthma education on asthma severity, quality of life and environmental control. Can Respir J 2000;7:395-400.

103. Cowie RL, Underwood MF, Little CB, Mitchell I, Spier S, Ford GT. Asthma in adolescents: A randomized, controlled trial of an asthma program for adolescents and young adults with severe asthma. Can Respir J 2002;9:253-9.

104. Shah S, Peat JK, Mazurski EJ, et al. Effect of peer led programme for asthma education in adolescents: Cluster randomised controlled trial. BMJ 2001;322:583-5.

105. Partridge MR. Translating research into practice: How are guidelines implemented? Eur Respir J Suppl 2003;39:23S-9S. 


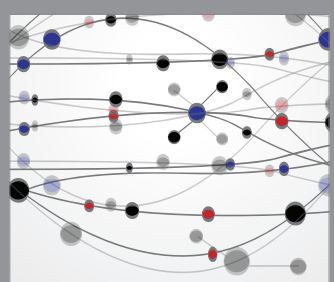

The Scientific World Journal
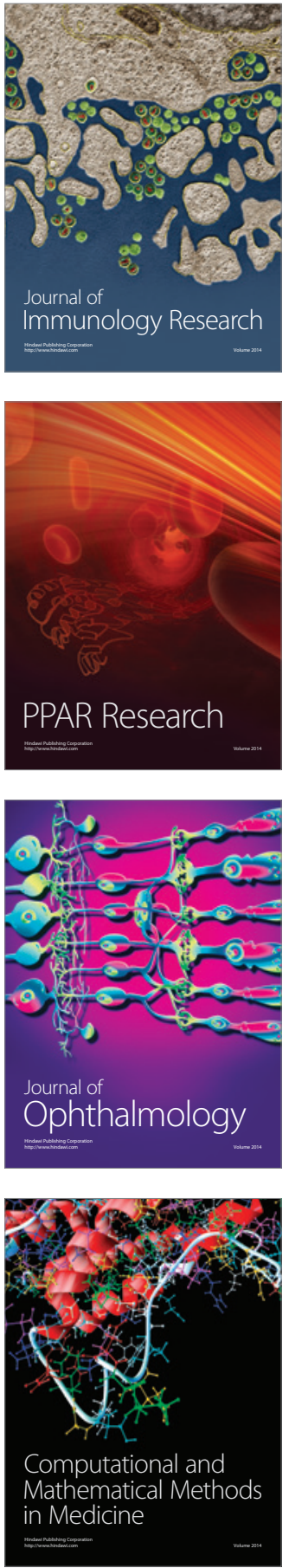

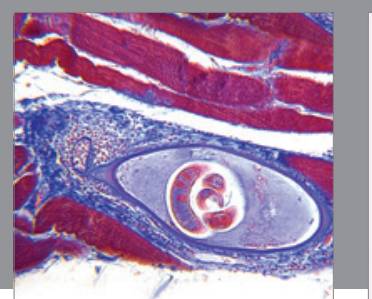

Gastroenterology Research and Practice

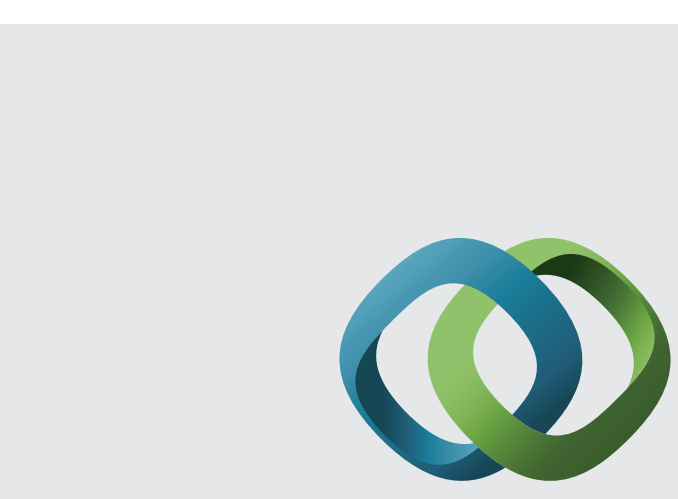

\section{Hindawi}

Submit your manuscripts at

http://www.hindawi.com
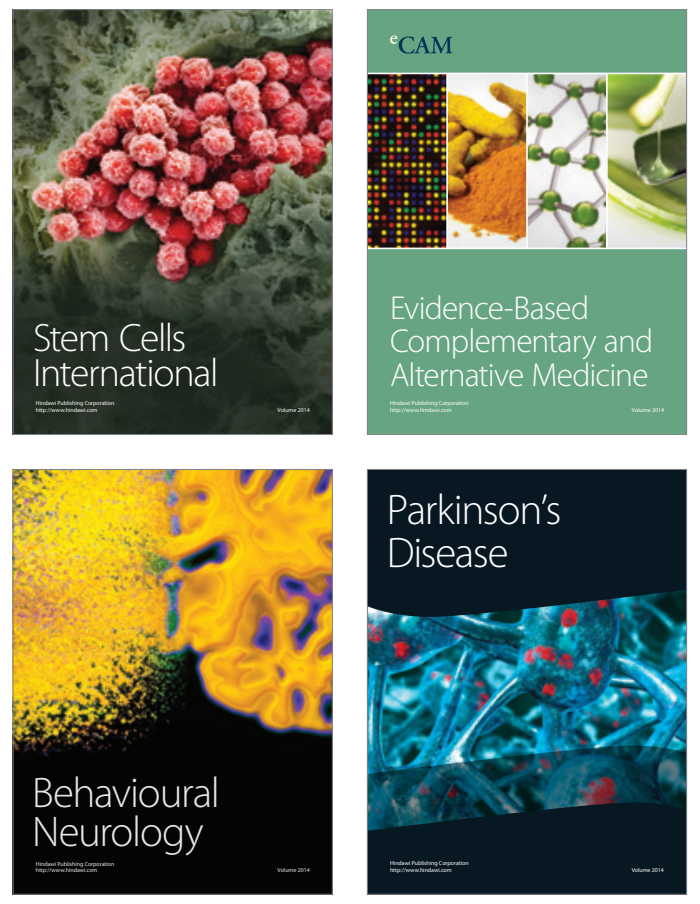
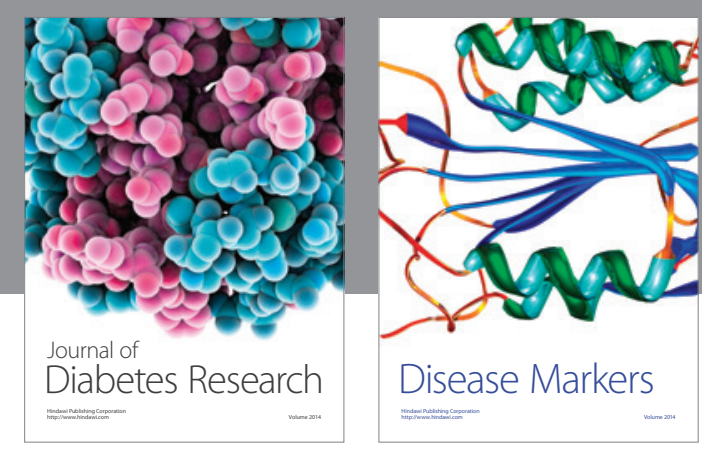

Disease Markers
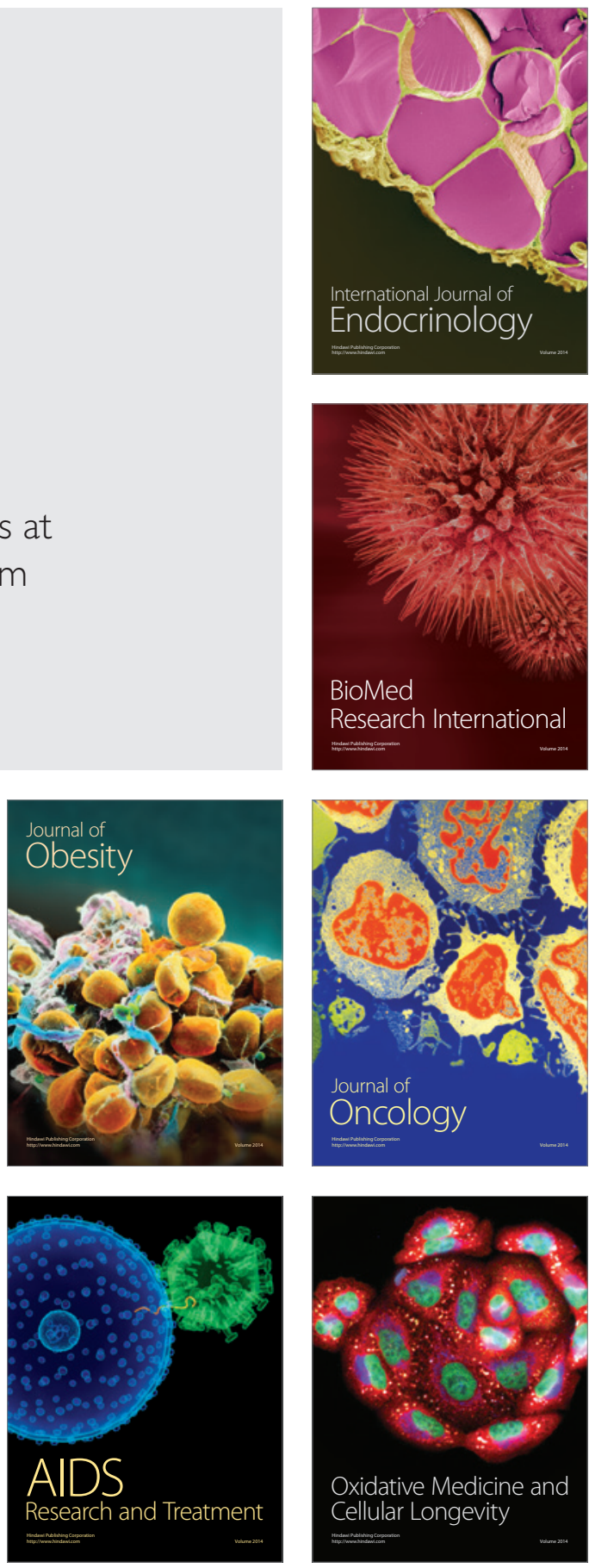